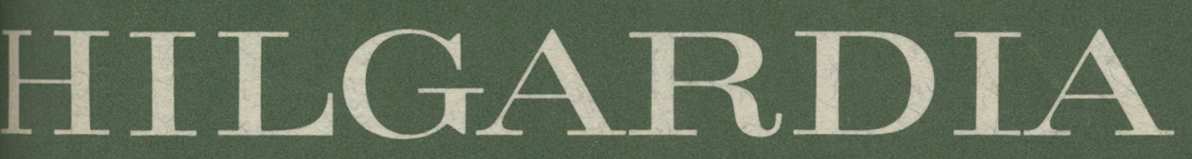

JOURNAL OF AGRICULTURAL SCIENCE PUBLISHED BY THE CALIFORNIA AGRICULTURAL EXPERIMENTSTATION

Volume 43, Number 3 - March, 1975

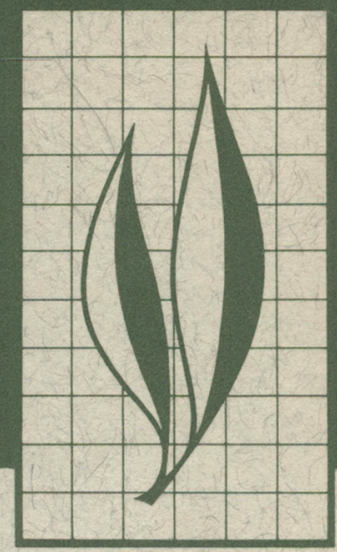

\title{
Microenvironment of a Dynamic Annual Community in Relation to Range Improvement
}

R. A. Evans, B. L. Kay, and J. A. Young 


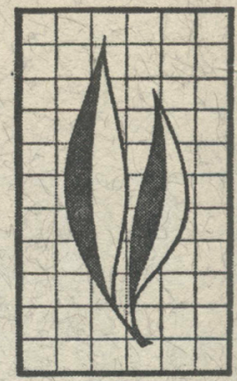

Syntheses of microenvironments based on monitoring are needed for understanding complex phenomena of an ecosystem and for establishing benchmark or standard regimes of temperature, light, and soil moisture for laboratory experiments involving seed germination, seedling growth, and other plant responses. These studies, in turn, answer questions about the dynamics of a plant community.

The microenvironment was monitored and vegetation was intensively sampled to interpret complex responses of an annual rangeland community to chemical weed control and reseeding.

Yield and density of plants varied among years, with aspect, within seasons, and in response to paraquat (1,1'-dimethyl-4,4'-bipyridinium ion). Establishment of hardinggrass and perlagrass (Pbalaris spp.) was related directly to paraquat treatment and reduction of competition from resident annuals. Species and aspect (north and south slope) differences were more important in establishment of annual clovers (Trifolium spp.), with reduction of competition not the overriding factor.

Available soil moisture permitted seed germination, seedling emergence, and growth of plants in this community. Temperature controlled the general rate of growth, and also created detectable differences in plant response when it dropped low enough to affect germination of seeds or caryopses or rose high enough to stress

(Continued on inside back cover)

\section{THE AUTHORS:}

Raymond A. Evans is Range Scientist, Agricultural Research Service, U. S. Department of Agriculture, Renewable Resources Center, University of Nevada, Reno, Nevada.

Burgess L. Kay is Specialist, Department of Agronomy and Range Science, University of California, Davis, California.

James A. Young is Range Scientist, Agricultural Research Service, U. S. Department of Agriculture, Renewable Resources Center, University of Nevada, Reno, Nevada. 


\section{Microenvironment of a Dynamic Annual Community in Relation to Range Improvement ${ }^{1}$}

\section{INTRODUCTION}

The annual Rangeland communities of California comprise a great variety of alien plant species. They were first introduced in 1769 with the coming of the Spanish Missions (Robbins, 1940) and continued through Gold Rush days. Even more recently, we have seen the startling invasion of such species as medusahead (Taeniatherum asperum (Sim.) Nevski) and barb goatgrass (Aegilops triuncialis L.). Alien annual species have replaced either native perennial grasses or native annuals and now constitute at least 50 per cent and, in many places, 90 per cent of the plant cover (Biswell, 1956). Of the almost 400 species of alien plants, some are well adapted and aggressive and are found widespread throughout California rangelands. Others are more restricted in site selection, but as a whole, they almost completely dominate the rangeland type.

Annual plants, more than perennial species, respond to differences in temperature and moisture regimes from year to year, because they must complete their life cycle from seed to maturity every year. This makes them more vulnerable than established perennial plants.

By their very nature, alien annual species are aggressive and highly competitive under the changed conditions brought about by grazing pressure (Evans and Young, 1972). The unique nature and abilities of alien annuals create plant communities that respond dynamically to many different environmental factors and to man's intervention and manipulation. Even subtle alterations of the environment may cause dramatic shifts in annual-plant communities. These shifts can be expressed as floristic changes, density changes, or production differences (Heady, 1958).

Because the alien annual species compete to such a high degree, replacing this vegetation with some other demands effective control measures. Many studies have shown the severe competitiveness of this community when revegetation is attempted. Cultivation for early control of the annual species, combined with grazing for continued control during the seedling stage of the replacement vegetation, has resulted in good establishment of hardinggrass (Phalaris stenoptera Hack.) and clover (Trifolium) species in many places (Love, 1952). The practicability of reseeding in these communities has been extended more recently by a combination of chemical control with paraquat

\footnotetext{
${ }^{1}$ Submitted for publication October 23, 1974. This is a cooperative investigation of the Agricultural Research Service, U. S. Department of Agriculture, the Agricultural Experiment Station, University of California, and the Agricultural Experiment Station, University of Nevada, Reno.
} 
(1,1'-dimethyl-4,4'-bipyridinium ion) spraying and of grazing (Kay and Owen, 1970).

Microenvironmental monitoring and detailed biologic sampling were conducted for 3 years to determine how vegetation responds in an annual range- land community to natural variability of environmental parameters and to artificial manipulations (chemical weed control and reseeding). This study was designed to measure individual microenvironmental parameters and relate vegetational responses to them.

\section{Procedure}

Studies were conducted during three growing seasons (1969-72). The site was a typical annual rangeland community of the Sierra Nevada foothills of northern California, at the Sierra Foothills Range Field Station of the University of California, about halfway between Grass Valley and Marysville. The site supports a sparse blue oak (Quercus Douglasii Hook \& Arn.)/digger pine (Pinus sabiniana Dougl.) woodland, with an understory dominated by annual grass. A few plants of perennial grass (Stipa spp.) hint at the structure of the pristine herbaceous community.

Average annual precipitation (196172 ) at the field station approximated 75 $\mathrm{cm}$. In the years of the study, it was 76 $\mathrm{cm}$ in 1969-70, $73 \mathrm{~cm}$ in 1970-71, and $45 \mathrm{~cm}$ in 1971-72 (average $65 \mathrm{~cm}$ ). Soil at the study site is classified as a complex of the Sobrante and Auburn series. Sobrante accounts for 95 per cent on the north slope and 90 per cent on the south slope. ${ }^{2}$ The Sobrante series is a member of the fine-loamy, mixed, thermic family of Mollic Haploxeralfs (formerly classified as Noncalcic Brown soils). Sobrante soils have reddish brown, medium acid, silt loam A horizons $(0$ to $12 \mathrm{~cm}$ ) and yellowish red, slightly acid, clay loam B horizons (12 to $60 \mathrm{~cm}$ ), which rest on weathered schist.

Trials were established on aspects facing both north and south, with slopes of 10 to 15 per cent. To establish plots on grazed areas each year, the peripheral fence was moved.

\section{Weed control and seeding treatments}

In each year of the study, paraquat was applied in the fall after emergence and early growth of annual plants. Dates of application varied by the time of the first effective rainfall: October 29, 1969; November 16, 1970; and December 7, 1971. Paraquat was sprayed at $1.12 \mathrm{~kg} / \mathrm{ha}$ with the surfactant X-77 at 0.1 per cent $\mathrm{v} / \mathrm{v}$. The herbicide-surfactant mixture was applied in water at 327 1/ha with a boom-type ground sprayer at a pressure of $2.11 \mathrm{~kg} / \mathrm{cm}^{2}$. Immediately after paraquat spraying, seeds of hardinggrass, perlagrass ( $P h a$ laris tuberosa var. hirtiglumis Batt. \& Trabut.), subclover (Trifolium subterraneum L.), and rose clover (T. hirtum All.) were drilled into the undisturbed soil. Unsprayed plots were also seeded in a like manner. Drilling was done with double-disk openers, followed by a press wheel. Seeds were placed in slits in the soil made by double-disk openers during drilling (Kay and Owen, 1970). Phosphorus and sulfur fertilizer as 0-20-0 at $112 \mathrm{~kg} / \mathrm{ha}$ was banded beneath clover seed at time of drilling.

Three-replicated random block trials incorporating sprayed and unsprayed plots were located on north- and southfacing slopes. Individual plot size was

\footnotetext{
2 Soil was classified and profiles described by E. L. Begg, Soils Specialist, Department of Boils and Plant Nutrition, University of California, Davis.
} 
3 by $15 \mathrm{~m}$, with four drill rows $40 \mathrm{~cm}$ apart through the middle of each plot. Two rows of perennial grass and one row each of rose and subclovers were seeded.

\section{Vegetation sampling}

The production index of annual plants was oven-dried weight of herbage. This index was calculated from three $0.1-\mathrm{m}^{2}$ samples per replication of each treatment plot, clipped weekly through the growing season. Production or biomass values were composited into four intervals during season and represent an average of 54 individual yield samples.

Density of annual species also was sampled weekly. For eight $6.5-\mathrm{cm}^{2}$ samples from each plot, a block of soil was cut out with a measuring fork and putty knife (Heady, 1958). When samples were composited from replications and grouped into four means through the season, each density value represented an average of 144 samples. Plants were separated by species and live ones were counted from each sample. Soft chess (Bromus mollis L.) and foxtail fescue (Vulpia megalura (Nutt.) Rydb.) were kept separate for presentation. Four species of Erodium-broadleaf filaree ( $\boldsymbol{E}$. botrys (Cav.) Bertol.), foothill filaree ( $E$. obtusiplicatum Maire, Weiller \& Wilez.), redstem filaree ( $E$. cicutarium (L.) L'Her.), and whitestem filaree ( $\boldsymbol{E}$. moschatum (L.) L'Her.) -were combined under the generic name.

A single group was made of other annual grass species: ripgut brome (Bromus rigidus Roth), Spanish brome (B. madritensis L.), slender wildoat (Avena barbata Pott ex Link), little quaking grass (Briza minor L.), Italian ryegrass (Lolium multiflorum Lam.), silver hairgrass (Aira caryophyllea L.), and medusahead.

Broadleaved plant species were also combined, the major ones being Micro- pus californicus F. \& M., smooth catsear (Hypochaeris glabra L.), erect plantain (Plantago hookeriana F. \& M. [ $P$. erecta Morris] var. californica (Greene) Poe), common chickweed (Stellaria media (L.) Cyrillo), bedstraw (Galium aparine L.), field chickweed (Cerastium visosum L.), Linanthus ciliatus (Benth.) Greene, woolly gilia (Navarretia intertexta (Benth.) Hook.), rattlesnake weed (Daucus pusillus Michx.), grass nut (Brodiaea laxa (Benth.) Wats.), and the legumes, Lotus micranthus Benth., bur clover (Medicago polymorpha L.), and Trifolium spp.

Frequency and density sampling and height measurements were used to evaluate establishment of perennial grasses and the introduced clovers. The introduced species were sampled monthly or at other specified times during the growing period. For forage production of the perennial grasses and for seed production of the clovers, yield was sampled in years after establishment. All sampling was done in relation to treatment and aspect.

\section{Microenvironmental monitoring and measurements}

Characteristics of the microenvironment were obtained by hourly monitoring of parameters of temperature, light, and soil water in the immediate proximity of both annual plant species and replacement perennial grass and clover species. Temperature was measured 1 $\mathrm{cm}$ below soil surface and $3 \mathrm{~cm}$ above. Soil water was measured 2,4 , and $8 \mathrm{~cm}$ below the surface.

The data-recording system used accommodated 90 individual data inputs. It was designed to operate unattended for up to 2 weeks on batteries and to have considerable tolerance to handling and to severity of the field environment, as is required for remote installation.

This recording system comprised four basic elements: sensors, scanner and 
programmer, signal conditioners, and recorders. The system was designed to accept many types of resistive sensory elements. Thermistors for measuring temperature had a base resistance of $3,000 \mathrm{ohms}$ at $25^{\circ} \mathrm{C}$. Light was measured with cadmium sulfide photocells with a peak spectral response of $550 \mathrm{~nm}$ and an effective sensing area of $1.17-\mathrm{cm}^{2}$. Resistance of these units is $166 \mathrm{kohms}$ at $22 \mathrm{lux}$ and $800 \mathrm{ohms}$ at 108 kilolux. Soil moisture was measured with gypsum blocks.

The scanner-programmer of the recording system allows variable input dwell-times ( 1 second to 3 hours) and variable repeat periods of the input scan (1 second to 3 hours). A dwell-time of 20 seconds for each input and a repeat period of 1 hour was used for the current studies. In this manner, each input was scanned for 20 seconds at the first of each hour. A 10-minute scanning period was required for the 90 inputs (30 inputs for each of three recorders). The recorders then ceased operation until automatic activation at the next hour.

Each of the three recorders has a signal conditioner. The conditioners convert the ohmic value of the transducer, connected through the scanner, into a signal of appropriate scale for driving the recording meters. These are alternating-current ohmmeter circuits with five decades of useful signal. In the current studies, only two scales were used. One has a midpoint value of 3,000 ohms and usable range from 200 to 15 ,000 ohms. The other has a midpoint value of $100,000 \mathrm{ohms}$ and a usable range of 10,000 to $1,000,000$ ohms. These two ranges relate well to the response of the sensors to environmental factors.

Besides automatic monitoring, soil moisture was measured weekly at 15 , 30 , and $45 \mathrm{~cm}$ below the surface. Gypsum blocks were used.

In the first part of May 1972, bisects were dug with a backhoe to study the soil profile, deeper soil moisture status, and depth of rooting of annual plants of the community. A bisect was dug on each slope at a right angle to the plots to expose the soil profile of each plot to a depth of $1.5 \mathrm{~m}$. Water potential of the soil was measured at three depths (20, 40 , and $80 \mathrm{~cm}$ ) in plots of all four treatments (north-slope check, north-slope paraquat, south-slope check, and southslope paraquat) with double-junction thermocouple psychrometers (Hsieh and Hungate, 1969). The rockiness of the soil's parent material precluded water-potential measurements below 80 $\mathrm{cm}$. To measure depth of rooting, 100$\mathrm{cm}^{3}$ samples from check and paraquat plots were taken on north and south slopes at nine depths $(0-1 \mathrm{~cm}, 2 \mathrm{~cm}, 5$ $\mathrm{cm}, 10 \mathrm{~cm}, 15 \mathrm{~cm}, 20 \mathrm{~cm}, 30 \mathrm{~cm}, 40 \mathrm{~cm}$, and $80 \mathrm{~cm}$ ). These samples were obtained from the side of the bisects at the midpoint intersection of each plot.

\section{RESULTS AND DISCUSSION}

\section{Soil moisture depletion}

Four causes of differences in soilmoisture depletion were found in these annual-plant communities. Most important were different precipitation patterns each year (table 1). Less important, though influential, were differences in regimes of day temperatures caused by aspect (comparison of north and south slopes) and weed control and seeding treatments.

Differences of soil-moisture depletion resulted from each of these comparisons because of an interplay of factors, including precipitation, temperature, light, and plant growth. Of course, plant growth is an index of moisture potential in soil, aside from direct-measurement techniques. 
TABLE 1

MONTHLY PRECIPITATION (CM) IN 3 YEARS OF THE STUDY, BEGINNING WITH THE FIRST EFFECTIVE RAINFALL FOR PLANT GROWTH OF THE SEASON

\begin{tabular}{|c|c|c|c|}
\hline Month & 1969 & 1970 & 1971 \\
\hline & \multicolumn{3}{|c|}{$\mathrm{cm}$} \\
\hline October.............. & 3.4 & 0 & 0 \\
\hline November......... & 4.4 & 11.2 & 0 \\
\hline December.......... & 20.3 & 34.0 & 24.8 \\
\hline January............ & 28.7 & 5.2 & 3.4 \\
\hline February........... & 6.3 & 1.9 & 5.9 \\
\hline March................... & 12.2 & 13.0 & 5.4 \\
\hline April.................... & 0.6 & 2.9 & 5.5 \\
\hline 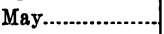 & 0 & 3.6 & 0 \\
\hline June..................... & 0 & 1.0 & 0 \\
\hline Total... & 75.9 & 72.8 & 45.0 \\
\hline
\end{tabular}

In 1969-70, although effective rainfall for germination and plant growth was earlier in the fall than in the next 2 years, two dry periods occurred immediately after paraquat spraying and seeding (October 29, 1969; fig. 1). In the 1st week after seeding, moisture potential of soil at 2 and $4 \mathrm{~cm}$ was reduced to -8 bars by rapid plant growth and lack of precipitation. A rain recharged the soil for the next 2 weeks, but in the following 2 weeks moisture potential of surface soil again reached -8 bars.

This period of alternate drying and wetting was extremely important to the seeded species because it occurred during seed germination and seedling emergence. Laboratory studies indicated that the germination of both the grasses $^{3}$ and clovers (Young et al., 1970 ) is reduced at -8 bars water potential at temperatures comparable to those in the field during this period.

Soil-water potential was at or near -0.3 bars for 15 weeks during winter when temperatures were too low for vigorous plant growth. Plant growth during March markedly increased with the advent of higher temperatures. Spring rains ceased early, and from the end of March to the end of April avail- able soil water was depleted to a depth of $45 \mathrm{~cm}$ (fig. 1).

Moisture depletion was less rapid on the north slope than on the south slope. This delay was less than 1 week in soil surface layers to almost 7 weeks at 45 $\mathrm{cm}$ in the paraquat-sprayed plots. On both slopes, the moisture-depletion rate was almost identical on treated and control plots.

In 1970-71, effective rainfall for plant growth commenced in November (table 1), and no dry periods occurred after seeding in mid-November; 26 weeks of high soil-moisture potential continued through winter and spring, with rainfall extending into June (fig. 2 ). Short periods of depletion occurred during this period, with a minimum moisture potential of -3 to -8 bars, except at $15 \mathrm{~cm}$ in check plots on the south slope where moisture was depleted to -25 bars for a short period (fig. 2). Near the end of the period of available moisture (middle to end of May), depletion was strikingly different at different soil depths and in relation to aspect. Minute differences occurred in relation to treatment. Depletion of available moisture occurred first at 15 , 30 , and $45 \mathrm{~cm}$ depths, in that order, and then at 4 and $8 \mathrm{~cm}$. Apparently, the zone of most active water absorption by roots was at $15 \mathrm{~cm}$ and then deeper to bedrock at the end of the growing season. Depletion of available water was more rapid on the south slope than the north, especially on paraquat plots.

In 1971-72, the first effective rain did not fall until December; thus spraying and seeding were much delayed (table 1 ). Soil moisture was available for 20 weeks after seeding (fig. 3 ). The wet period extended until the first of May, with one period of drying to -20 bars in early April at $15 \mathrm{~cm}$ in control plots of the south slope and a lesser period of depletion in other plots and other soil depths.

\footnotetext{
- Unpublished data, Agricultural Research Service, USDA, Reno, Nevada.
} 


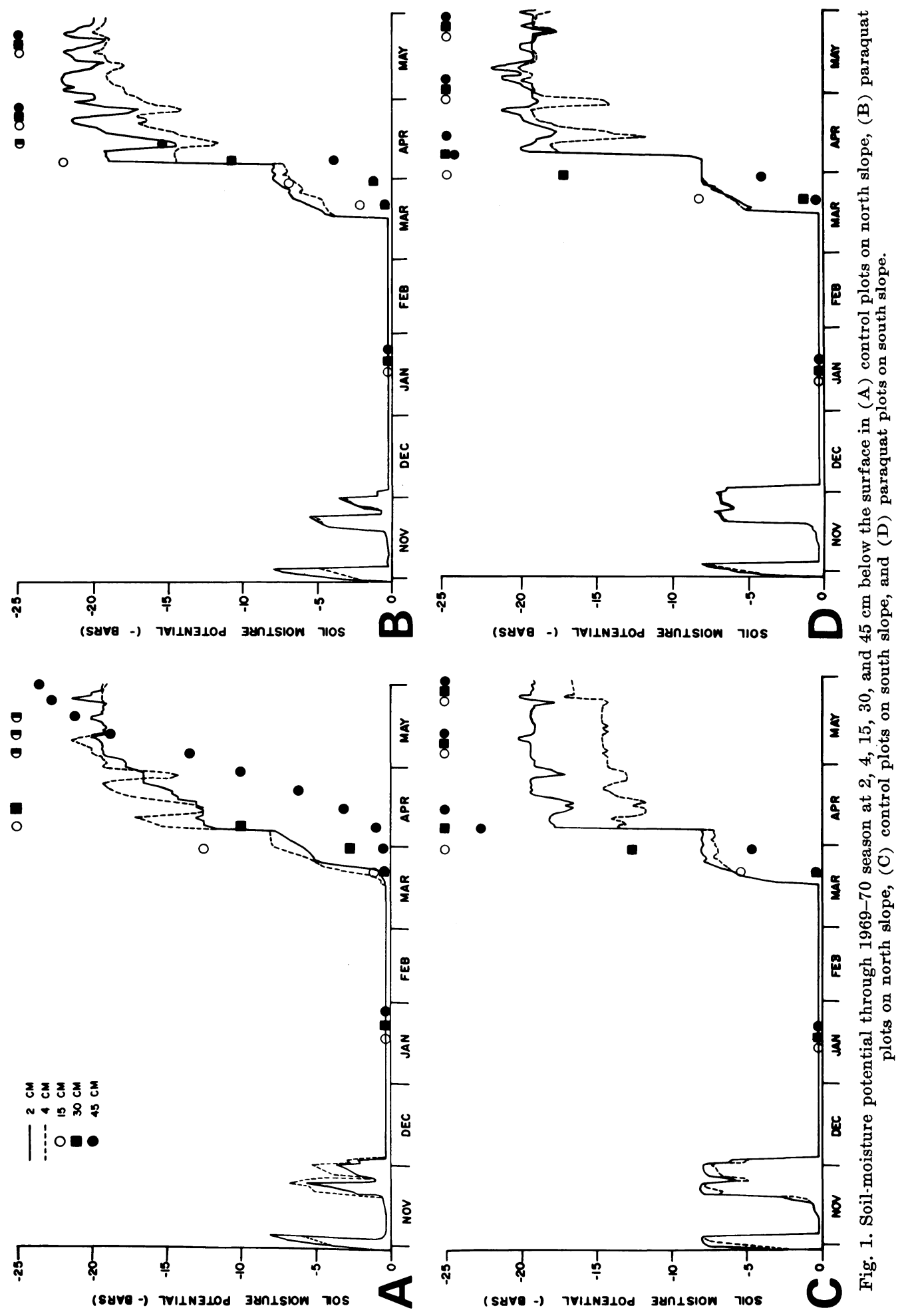



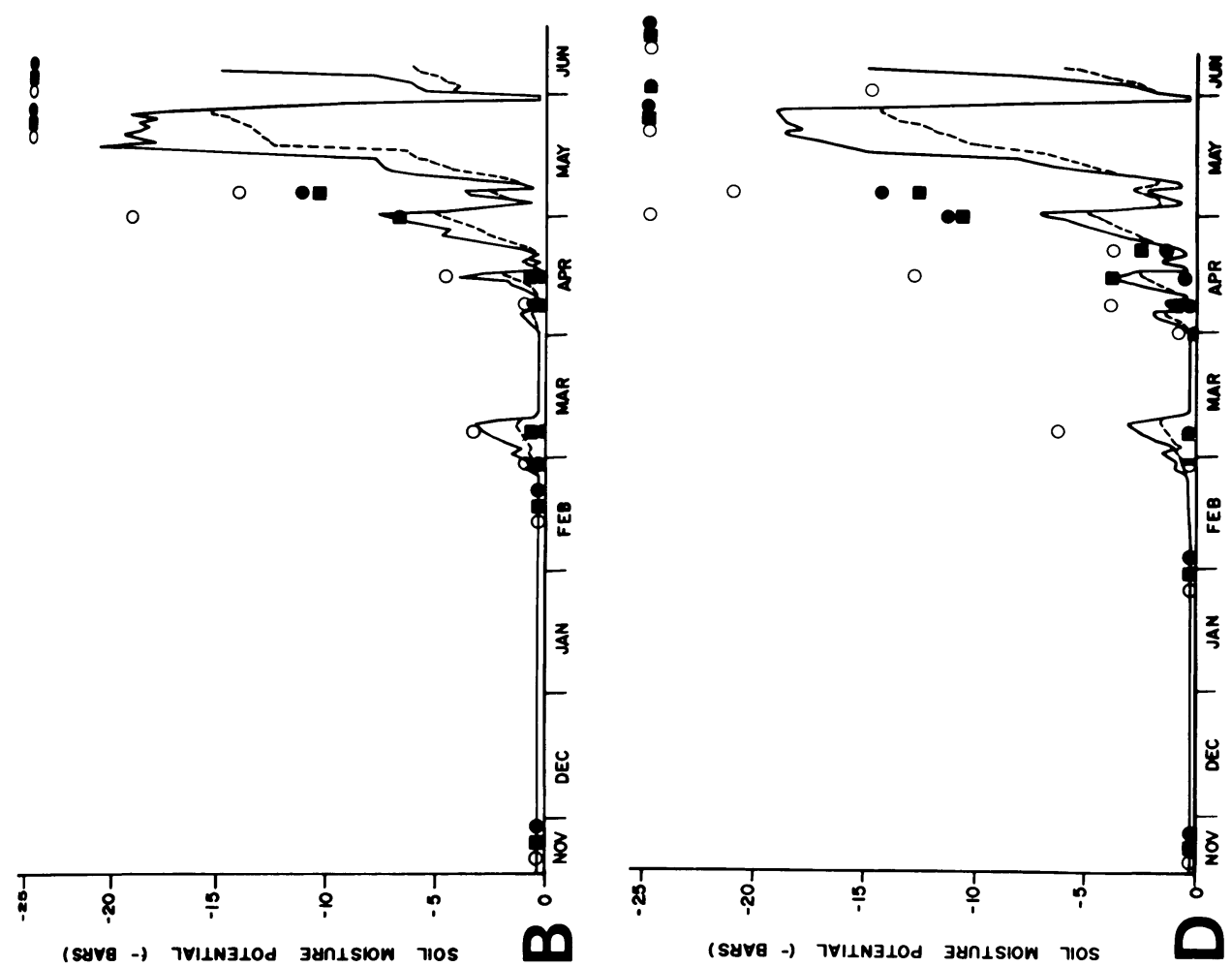

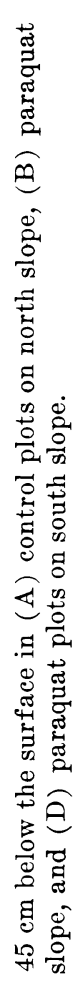

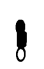

8
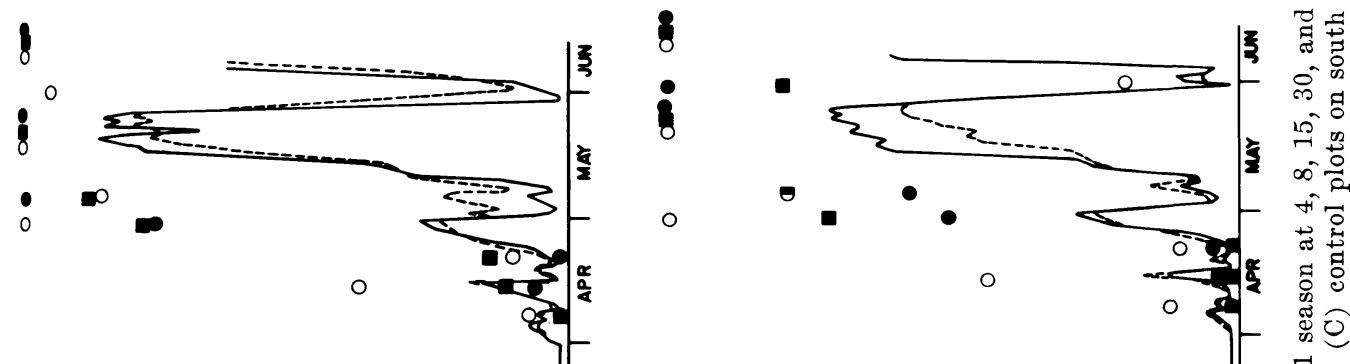

0

$10^{-8}$

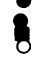

○

$\nabla$

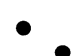

$\infty \frac{0}{0}$

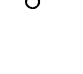

정정정정
으웅
|'000
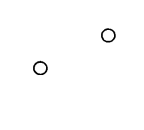

\{\}

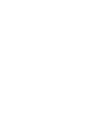



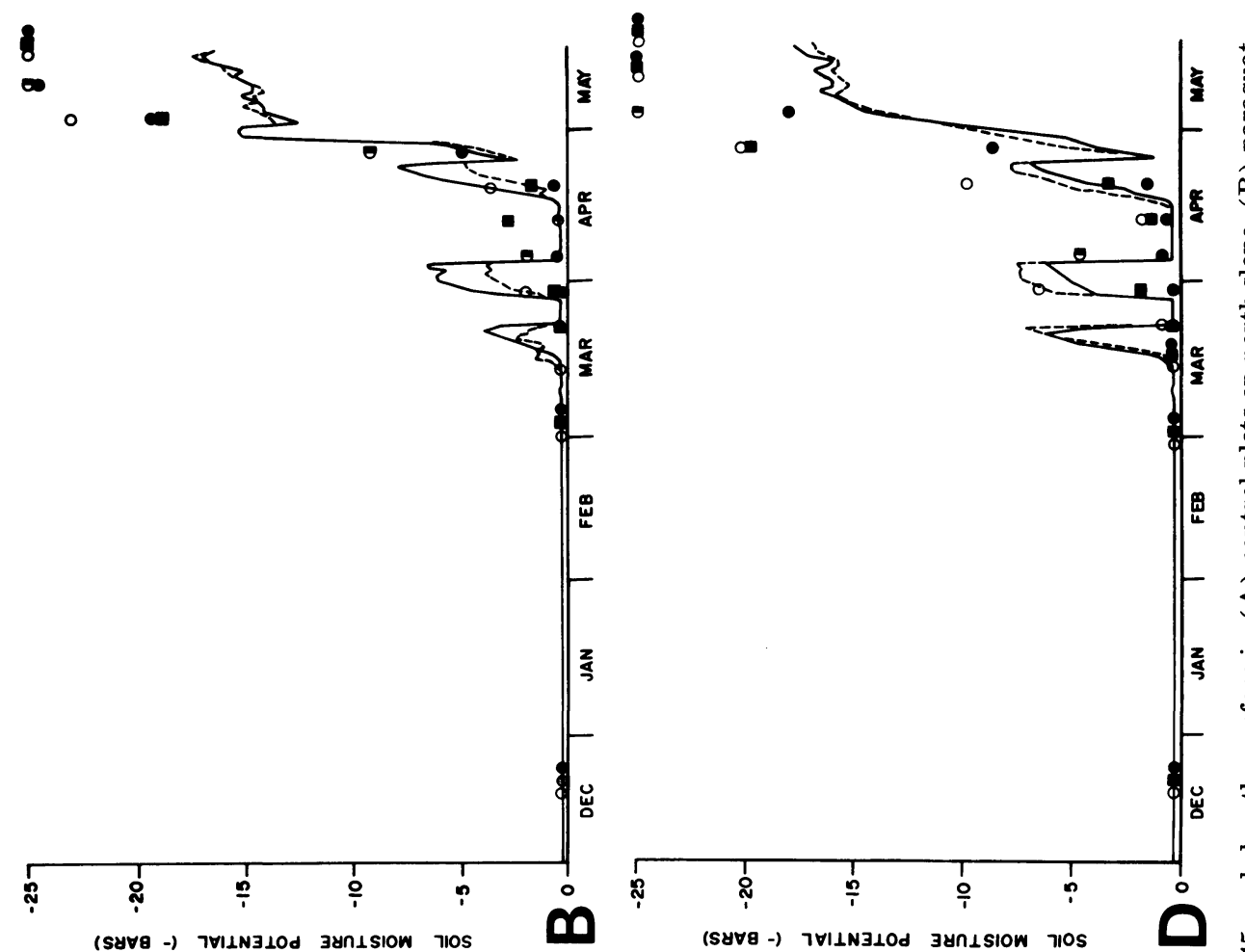

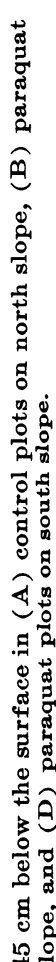
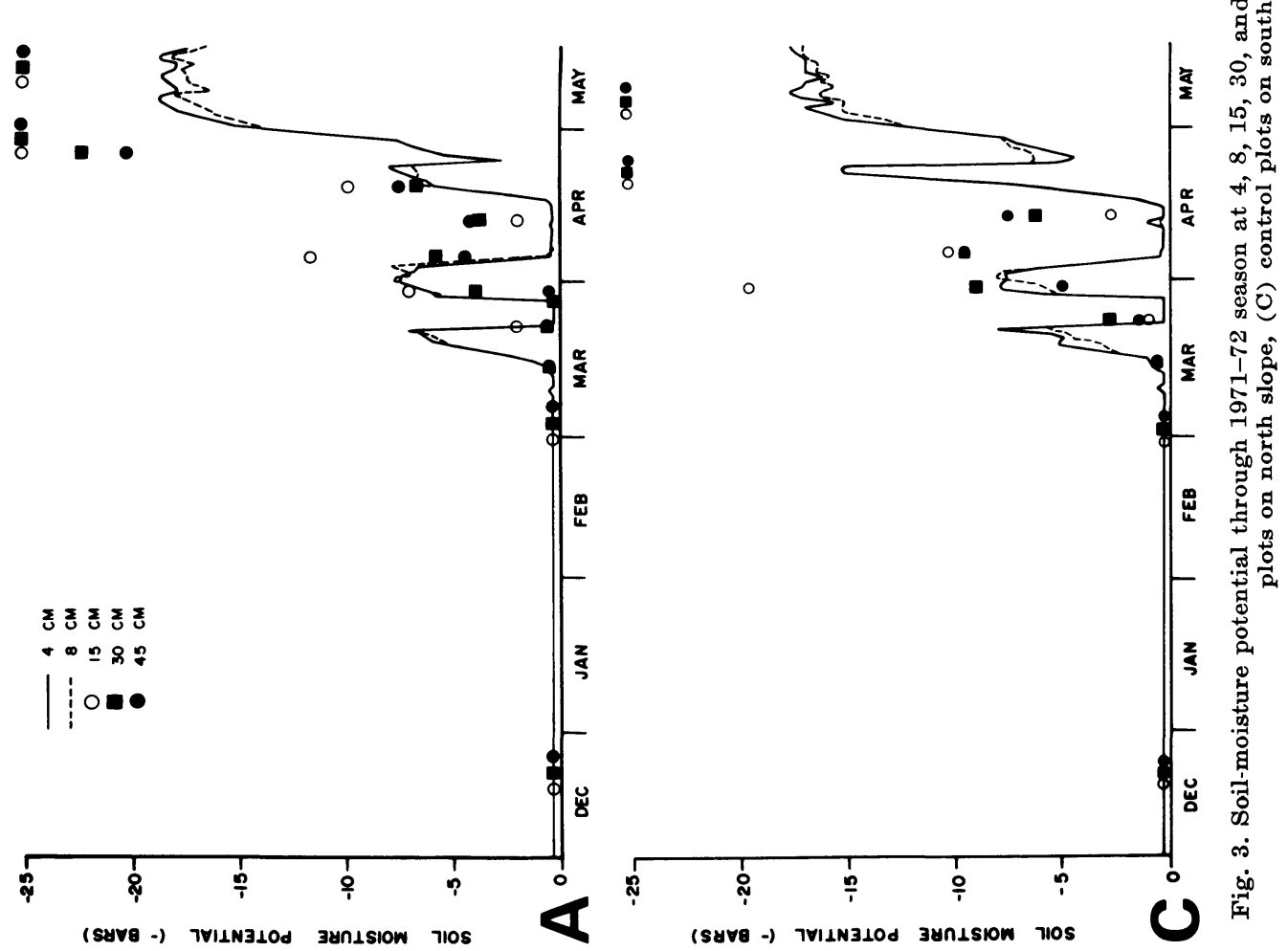
In the first part of May, 1972, water potentials (measured with thermocouple psychrometers at $20 \mathrm{~cm}$ ) were from -30 to -50 bars tension, with the lower potentials on check plots. Potentials at $40 \mathrm{~cm}$ varied from -26 to -40 bars, and from -23 to -40 bars at $80 \mathrm{~cm}$. At deeper levels, the south-slope check plots had the lowest water potentials and the north-slope check plots the highest, with paraquat plots intermediate.

Although the soil profile had no measurable water available to plants in the first $80 \mathrm{~cm}$ (at this depth, parent material consisted of fractured greenstone rocks), the vegetation was still somewhat green and had not dried completely.

The pattern of root distribution (fig. 4) indicates that most roots (92 per cent) are found in the upper $10 \mathrm{~cm}$ of soil, but water-depletion patterns indicate that the zone of most root activity in mid and late growing seasons is at $15 \mathrm{~cm}$ and deeper. Even in the parent material at $1 \mathrm{~m}$ or deeper, roots were found along fractures in the rocks in clay films and in May, plants must have been getting significant water from soil at those depths.

There were no statistically significant differences between treatments (check vs paraquat) or with aspect (north vs south slopes) in terms of root weight, either in the entire profile or at any depth. Numerical differences indicated fewer roots on paraquat plots and on the north slope, especially in the surface layers of soil.

Year-to-year variation of soil-moisture availability is most important in this annual rangeland. This relation depends mainly on precipitation, but is influenced secondarily by temperature (either directly or through differences in plant growth). Of primary concern are soil-water conditions, both immediately after the seeding of replacement species and at the time of accelerated

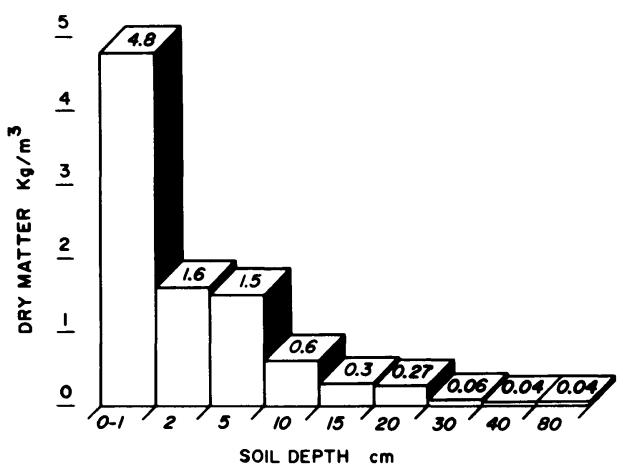

Fig. 4. Dry weight of roots at specific depths in the soil from the surface to $80 \mathrm{~cm}$.

growth in the spring, when temperatures permit optimum growth.

Differences between slopes in available soil moisture were consistent but not usually large. The south slope tended to be drier, especially toward the end of the season, and soil-moisture depletion was greater during dry periods in midseason. A greater thickness of soil horizons and depth to bedrock on the north slope resulted in higher water-holding capacity and available soil moisture than on the south slope. Also, the percentage of coarse fragments was greater on the south slope, thus reducing available soil moisture.

Treatment differences were usually not large in terms of soil-moisture depletion. Here again, midseason differences during dry periods tended to be greater than differences of season-long depletion. In Nevada, paraquat spraying for downy brome control and seeding in the big sagebrush community resulted in a dramatic storage of moisture in the soil (Evans et al., 1970). In the California annual rangeland community, reestablishment and later growth of weeds on sprayed plots were greater than those in the downy brome community. Even though plant density was lower than that in unsprayed plots, there were enough large weeds near the 


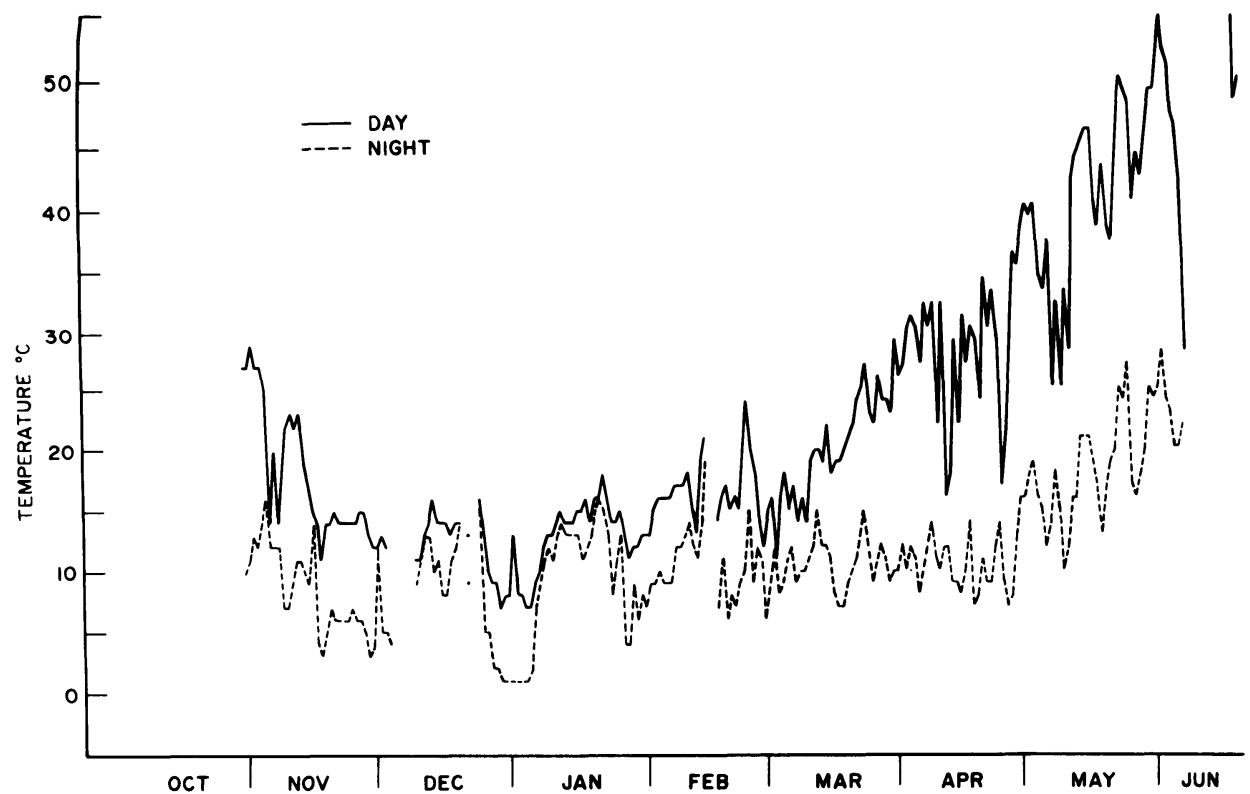

Fig. 5. Day ( $8 \mathrm{AM}$ to $7 \mathrm{PM}$ ) and night ( $8 \mathrm{PM}$ to $7 \mathrm{AM}$ ) average air temperatures ( $3 \mathrm{~cm}$ above soil surface) on the south slope through the growing season in 1969-70.

end of the growing period to deplete the soil of moisture. Young and Evans (1972) showed a similar dynamic response of annual grasses in terms of yield vs frequency in a medusaheaddowny brome community.

\section{Temperature}

Seasonal trends of air (3 $\mathrm{cm}$ above surface) and soil ( $1 \mathrm{~cm}$ below surface) temperatures, expressed as day (8 AM to $7 \mathrm{PM}$ ) and night ( $8 \mathrm{PM}$ to $7 \mathrm{AM}$ ) averages, were quite similar in the 3 years of the study, with only two recognizable variations from the average (figs. 5, 6, and 7). Air day temperatures averaged about $5^{\circ}$ to $15^{\circ} \mathrm{C}$ in December and January, $10^{\circ}$ or $15^{\circ}$ to $30^{\circ} \mathrm{C}$ in March and April, and $25^{\circ}$ to $45^{\circ} \mathrm{C}$ in May and June. Air night temperatures averaged $0^{\circ} \mathrm{C}$ or slightly below to $15^{\circ}$ $\mathrm{C}$ in December and January, $5^{\circ}$ to $15^{\circ}$ or $20^{\circ} \mathrm{C}$ in February, March, and April, and $10^{\circ}$ to $25^{\circ}$ or $30^{\circ} \mathrm{C}$ in May and June. Both day and night average air temperatures varied greatly from day to day.

Soil temperatures ( $1 \mathrm{~cm}$ below surface) were generally the same as air temperatures ( $3 \mathrm{~cm}$ above the soil surface) during the day, except in early fall before germination of plants. Then, soil temperatures were somewhat higher. The layer of vegetation above the soil appeared to negate the usual differences of soil and air temperatures (Evans and Young, 1970). Soil temperatures at night were the same or slightly higher. There were no detectable differences in temperature between paraquat-sprayed plots and unsprayed plots. These data are not presented.

The aforementioned trends of air temperature show the characteristic pattern of the Mediterranean-type climate of this part of California. Temperatures are low in winter and early spring, preventing rapid growth of the annual species; high temperatures in early fall, late spring, and early sum- 


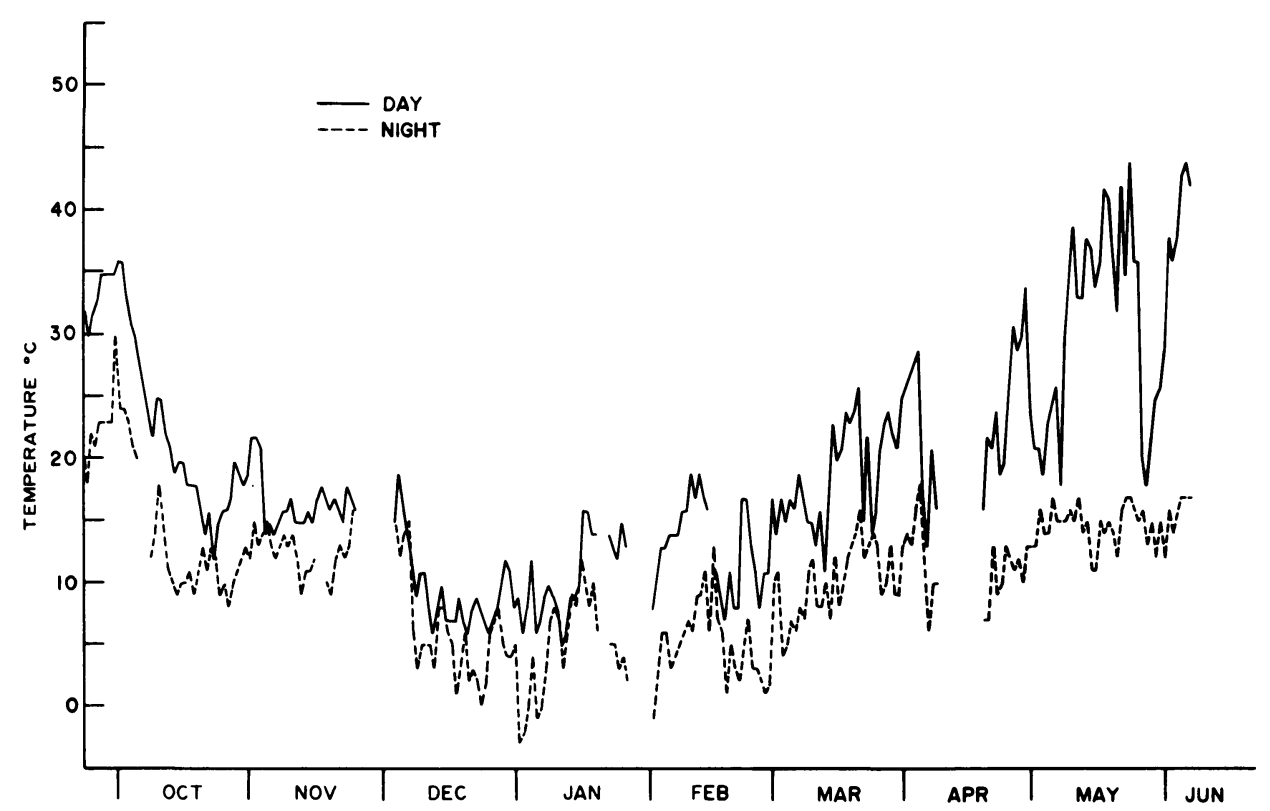

Fig. 6. Day (8 AM to $7 \mathrm{PM}$ ) and night ( $8 \mathrm{PM}$ to $7 \mathrm{AM}$ ) average air temperatures ( $3 \mathrm{~cm}$ above soil surface) on the south slope through the growing season in 1970-71.

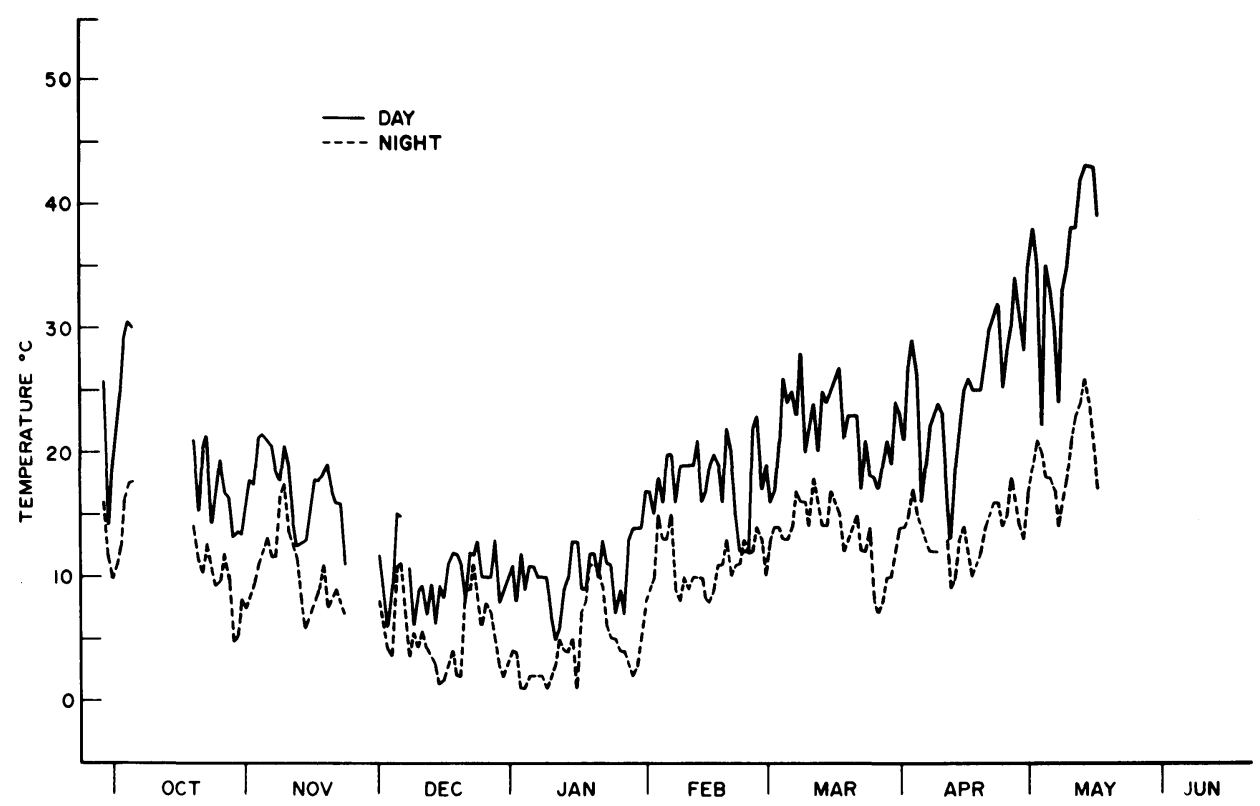

Fig. 7. Day ( $8 \mathrm{AM}$ to $7 \mathrm{PM}$ ) and night ( $8 \mathrm{PM}$ to $7 \mathrm{AM}$ ) average air temperatures ( $3 \mathrm{~cm}$ above soil surface) on the south slope through the growing season in 1971-72. 
mer create stress conditions-both directly and indirectly (by rapid depletion of soil moisture through increased transpiration of plants).

In 1970-71, night temperatures beginning in December through the middle of March were consistently lower than those in the other 2 years. This cold could definitely affect plant establishment and growth, because temperature in this period ordinarily becomes a limiting factor by reducing or negating seed germination (Evans et al., 1973; Young et al., 1973) and by retarding seedling growth of species in this plant community. Plant densities were much lower in this year than in either of the other 2 years (table 2 ).

Day temperatures in April, May, and June were higher in 1969-70 than those in the other 2 years. Soil-moisture depletion was more rapid, and drying of the annual plants was earlier in that year. The early maturation and drying of plants resulted from both the cessation of rainfall in April and May and the higher-temperature regime.

Both day and night temperatures were generally $2^{\circ} \mathrm{C}$ to more than $10^{\circ} \mathrm{C}$ higher on the south slope in any 24-hour period. These differences in temperatures, along with the shallower soil, made conditions slightly drier on this aspect. Only south-slope temperatures are presented in figures 5,6 , and 7 because patterns were similar on both slopes throughout the season.

Plant litter covering the soil surface provides the germination media for many of the annual grass species in this community. Differential potential among species in adaptation to germination in the litter and in relation to temperature probably determines the annual-species composition of these communities (Young et al., 1971).

\section{Light relations}

During periods of favorable moisture conditions, the skies are often cloudy, and illumination is low. At this time, temperatures are also too low for vigorous plant growth. As a result, plants of seeded species remain small, in many instances not much larger than seedlings, for the entire winter and early spring. During this period, annual plants form a complete canopy cover, making competition crucial for light at the soil surface level for seedlings of seeded species.

For 4 months (December, January, February, and March) of 1969-70, the intensity of light reaching the ground level averaged below 10 kilolux and was often as low as 2 kilolux for the 5 hours of maximum solar radiation during the day on check plots (fig. 8). These low levels occurred on both north and south slopes. Light intensity was reduced also by interception of the plant canopy on paraquat-sprayed plots. In this year, spraying was not as effective as usual, with a relatively high resultant density and production of annual species on sprayed plots (tables 2 and 3 ). On the north slope, intensity of light at ground level during the 4 months was reduced to 35 per cent of the total incoming radiation by shading from annual plants on paraquat plots and was reduced to 20 per cent on control plots. On the south slope, light reductions were to 37 per cent on paraquat plots and 9 per cent on control plots, as compared to values where no canopy interception occurred.

On the north slope, because of lower total radiation ( 32 per cent less light intensity than on the south slope) in both check and paraquat plots, groundlevel light intensity remained low from December to March. On the south slope during this period, light intensity at ground level fluctuated greatly from day to day in paraquat plots, with relatively high values (up to 30 kilolux on specific days). Underneath undisturbed vegetation on control plots, 

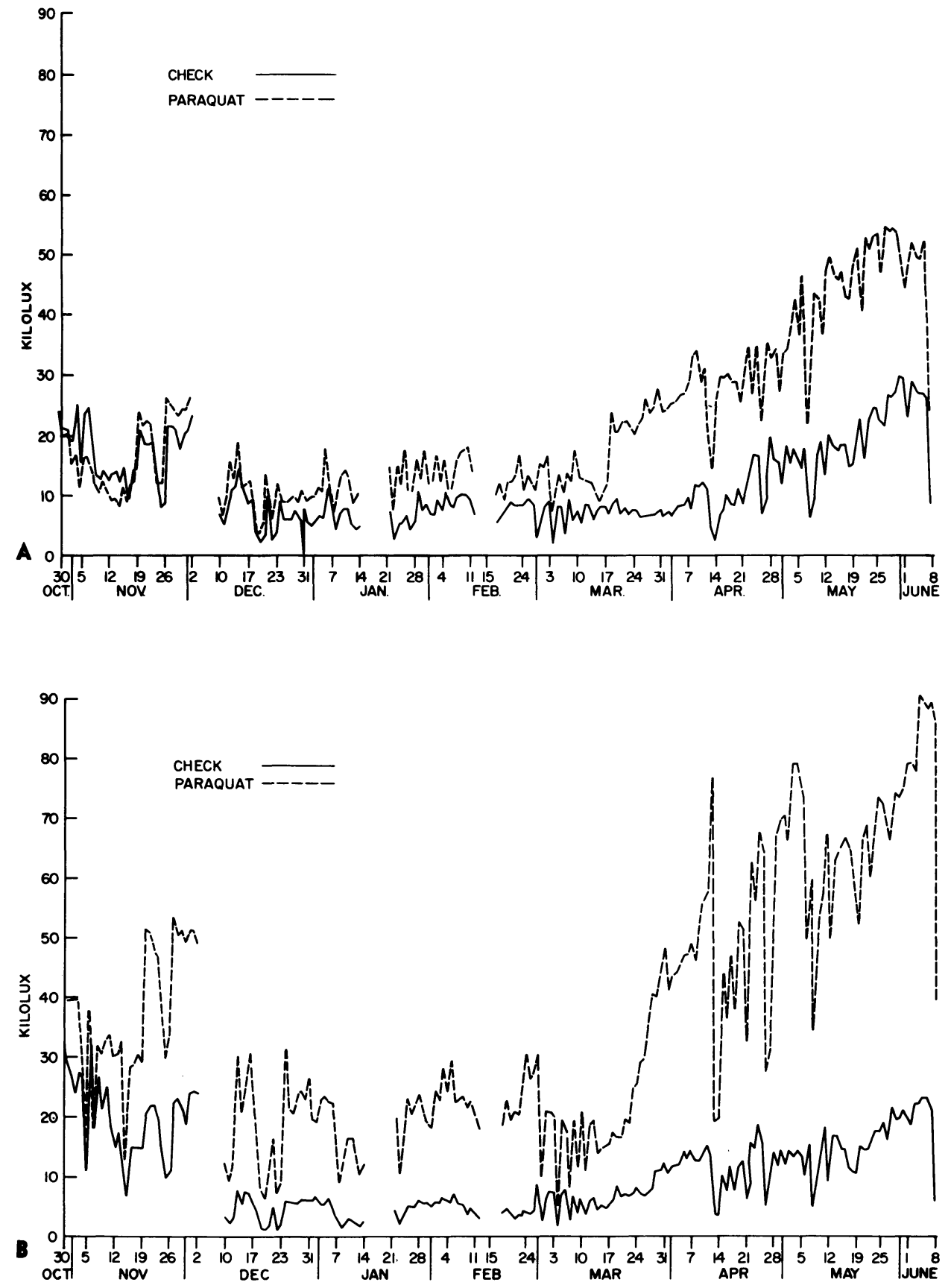

Fig. 8. Illumination in 1969-70 at the soil surface (average of 5 hours of maximum radiation) in (A) north-slope check and paraquat plots and (B) south-slope check and paraquat plots. 

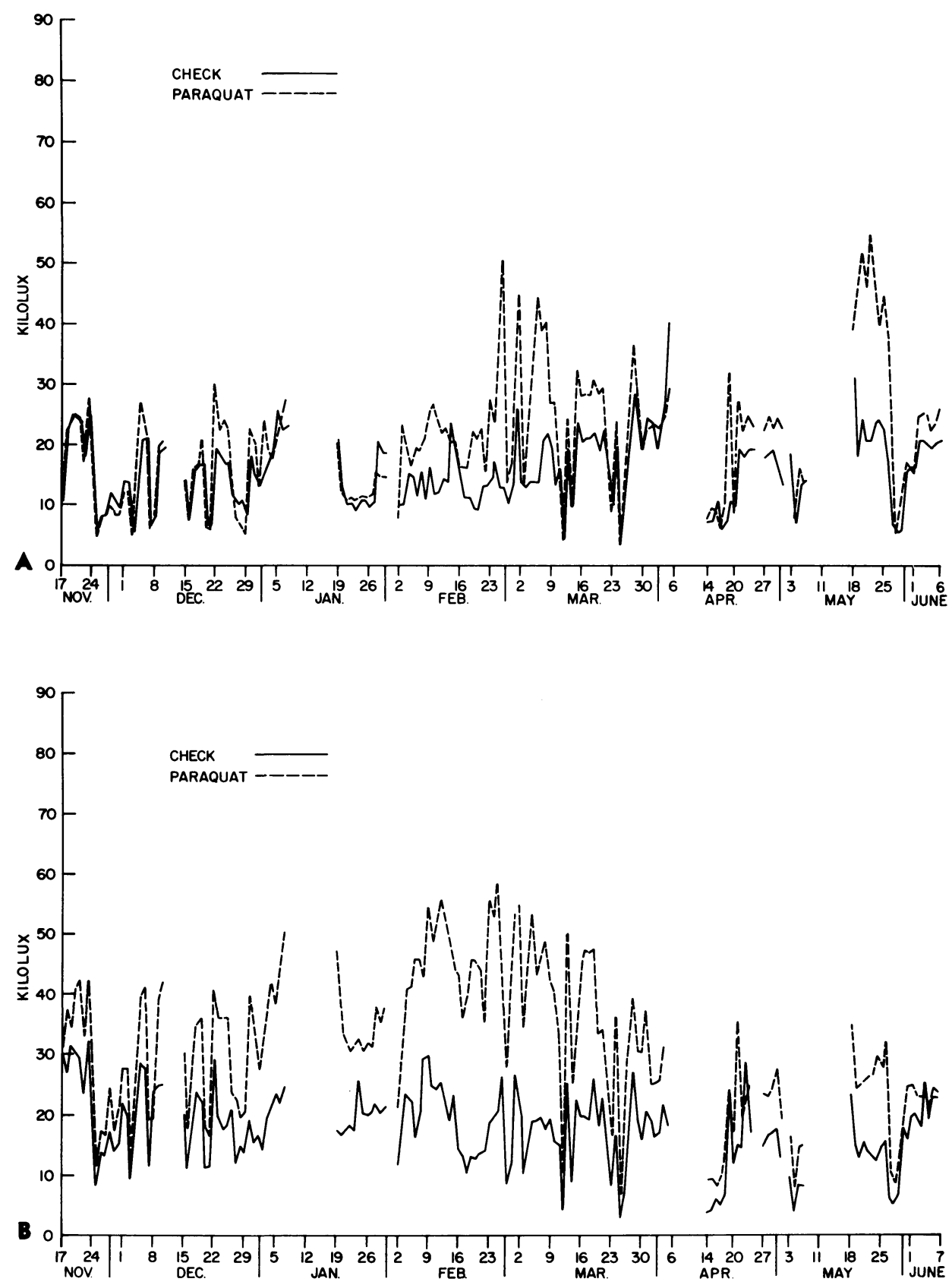

Fig. 9. Illumination in 1970-71 at the soil surface (average of 5 hours of maximum radiation) in (A) north-slope check and paraquat plots and (B) south-slope check and paraquat plots. 
however, light intensities remained very low.

Light intensities during April, May, and June steadily increased on paraquat plots, but remained low on control plots, because herbaceous plants with high density and production caused severe shading.

In 1970-71, the overall lower density of plants and extremely good kill of vegetation with paraquat gave light relations different from those in the previous year (fig. 9). Aspect relations remained similar, with illumination lower on the north slope under both paraquat and control conditions. Illumination at the ground level was somewhat higher under all conditions of vegetation than it was in 1969-70. In December through March, maximum diurnal light intensities at ground level on the north slope ranged between 5 and 25 kilolux on control plots and between 5 and 50 kilolux on paraquat plots. On the south slope, light intensities varied between 5 and 30 kilolux on control plots and between 5 and 60 kilolux on paraquat plots.

On the north slope, illumination penetrating through the plant canopy to ground level was 41 per cent of total in control and 53 per cent in paraquat plots. On the south slope, the penetration was respectively 38 per cent and 77 per cent. Six centimeters above the soil surface, there was no shading effect during these 4 months on either slope, though illumination at this height was 28 per cent less on the north slope than on the south slope.

In 1971-72, a trend of low light values on control plots in winter and early spring months was again evident, as in the two preceding years (fig. 10). In February, when shade competition was most evident, reduction of light by the plant canopy on control plots on the south slope made the intensity at ground level only 15 per cent of that $6 \mathrm{~cm}$ above the soil surface (fig. 11).
On paraquat plots, decrease was only to 88 per cent. In contrast, on the north slope the paraquat plots had at ground level only 57 per cent of the light they had at $6 \mathrm{~cm}$ above, and check plots had 48 per cent. Light intensity $6 \mathrm{~cm}$ above the ground was slightly lower on the north slope than on the south, though not with a statistical significance. At ground level in February, however, light intensities on paraquat plots were lower on the north slope than on the south slope.

On March 10, 1972, the photocells at ground level were raised to $3 \mathrm{~cm}$ above the soil surface to ascertain light interception at an intermediate height in the canopy. Canopy interception of light on control plots was far less at $3 \mathrm{~cm}$ than at ground level. These light intensities were similar to those on paraquat plots on days of high illumination. On days of low illumination, light intensities at $3 \mathrm{~cm}$ were consistently lower on control plots than on paraquat plots. Light values were similar at 3 and $6 \mathrm{~cm}$. A trend towards less illumination at $3 \mathrm{~cm}$ was most evident on south-slope paraquat plots. On both north and south slopes, light values at $6 \mathrm{~cm}$ were lower on control plots than on paraquat plots beginning in April.

In all 3 years light relations were similar in terms of canopy interception, aspect, and height above soil surface. The results graphically show light interception by the canopy of annual plants. This effect is most pronounced at the ground level and during the germination, emergence, and early growth of seeded species. Canopy interception of light is much less $3 \mathrm{~cm}$ above the soil surface, and at $6 \mathrm{~cm}$ annuals shade other plants but little until near the end of the growing period in spring.

When reviewed in terms of plant competition and the growth and establishment of seeded species, these light relations become the most important factor in the success or failure of arti- 

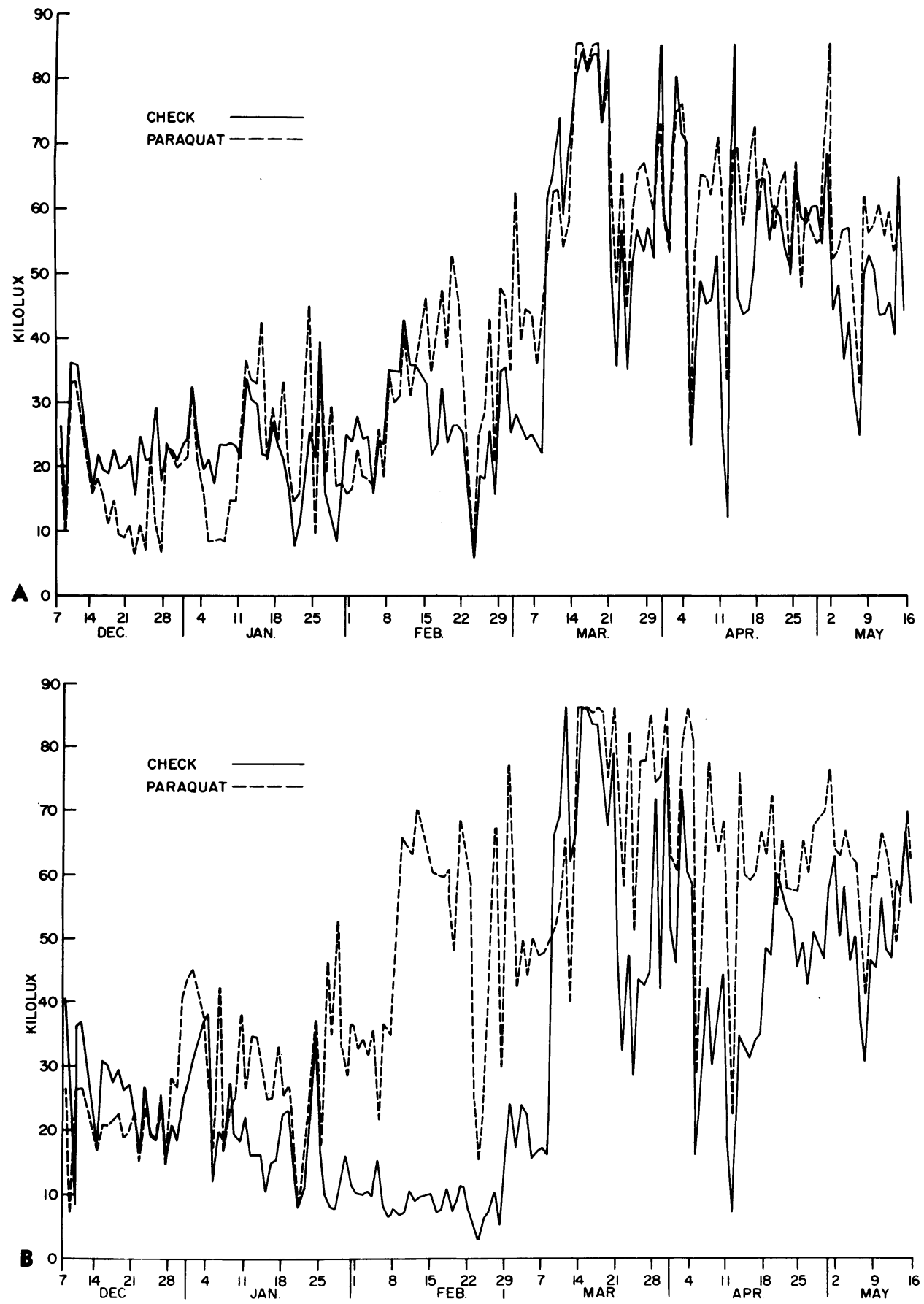

Fig. 10. Illumination in 1971-72 at the soil surface (average of 5 hours of maximum radiation) in (A) north-slope check and paraquat plots and (B) south-slope check and paraquat plots. On March 10, 1972 the photocells at ground level were raised to $3 \mathrm{~cm}$ above the soil surface. 

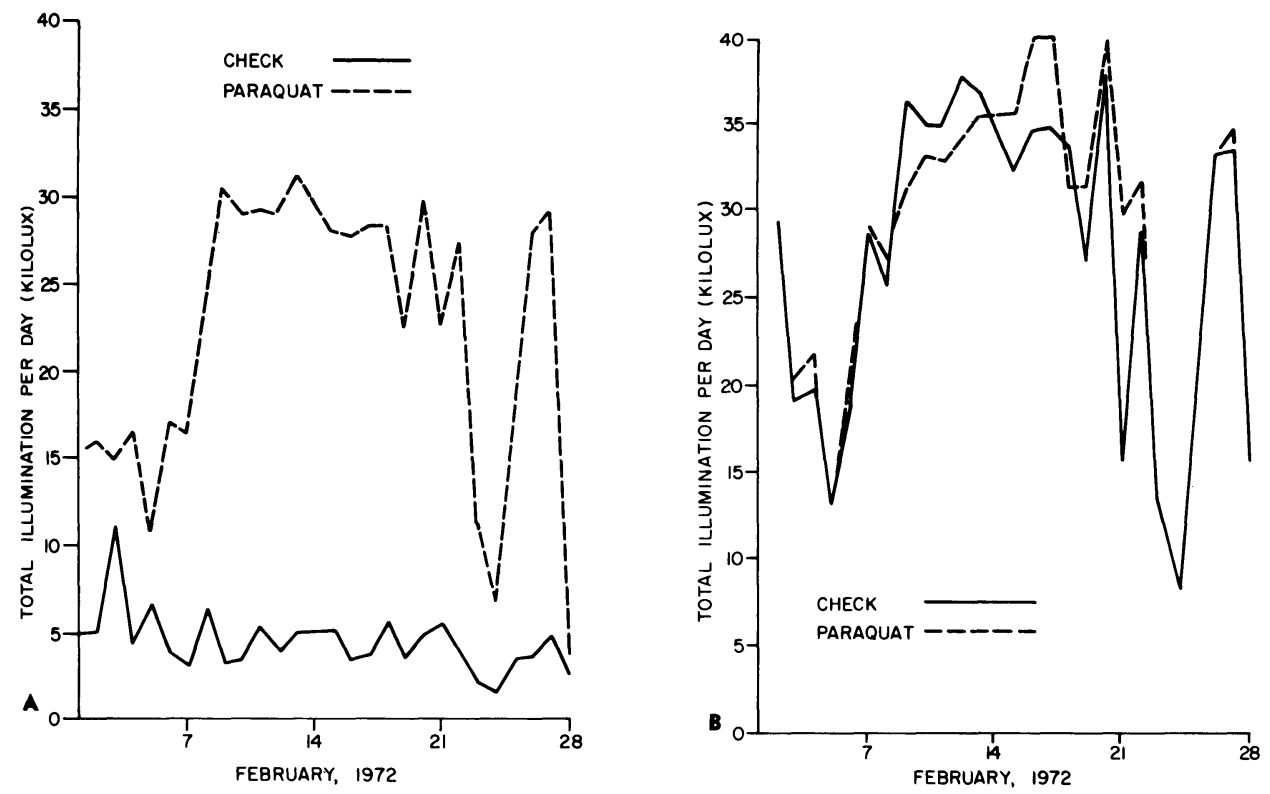

Fig. 11. Total illumination/day in south-slope check and paraquat plots in February 1972 at (A) the soil surface and (B) $6 \mathrm{~cm}$ above the soil surface.

ficial seeding in this annual-rangeland community.

One of our replacement species was subclover, which other studies have shown to be poorly adapted to any light regime that departs greatly from full exposure (Hughes, 1966). Hardinggrass, another replacement species, has notoriously weak seedlings which are undoubtedly affected to a great extent when light intensity at the soil surface is lowered by canopy closure of annual plants. Although perlagrass has a more robust seedling than hardinggrass, it also was affected by the shading of annual plants.

\section{Responses of annual plants}

Density. Density (number per unit area) of annual plants varied among years, between sites on north and south slopes, during a specific season of growth, and in response to paraquat application (table 2). Maximum average density was about 500 plants per
$100 \mathrm{~cm}^{2}$ on both slopes in 2 years (196970 and 1971-72). In 1970-71, densities were lower, with a maximum average of 240 plants per $100 \mathrm{~cm}^{2}$ on the north slope and 160 on the south. Density was consistently higher on north than on south slopes in each year of the study. Generally, density tended to decrease through the season; however, on the north slope in 1969-70 density remained high until April. By May or June, densities were drastically reduced by increased temperatures and the unavailability of water in the soil.

Paraquat generally reduced plant numbers, but did not give uniformly effective plant control in each year. Density of annual plants was markedly reduced at first and throughout the season in 1970-71 and 1971-72, but only minimally in 1969-70. Weed control by paraquat was not as effective in 1969-70 because at time of spraying, emergence of the resident annuals was only 28 per cent on the south slope and 38 per cent 
on the north (table 2). In 1971-72 on the south slope there was low emergence of annuals at time of spraying, but the effect on resultant density was not as striking.

Biswell and Graham (1956) at the San Joaquin Experimental Range in the central Sierra foothills and Heady (1958) at the Hopland Field Station on the north coast of California indicated similar trends of decreasing plant density through the growing season or from seedlings to mature plants. Densities of annual plants varied from 2247 per $100 \mathrm{~cm}^{2}$ (very dense stand of foxtail fescue) to 113 per $100 \mathrm{~cm}^{2}$ (stand of 90 per cent cover of broadleaf filaree) at the San Joaquin Experi-

TABLE 2

BOTANICAL COMPOSITION IN TERMS OF DENSITY OF STANDS ON NORTH AND SOUTH SLOPES, SPRAYED WITH PARAQUAT AND UNSPRAYED

\begin{tabular}{|c|c|c|c|c|c|c|c|c|}
\hline \multirow{2}{*}{ Time of sampling } & \multicolumn{8}{|c|}{ North check* } \\
\hline & Brmo & Vume & OG & $\begin{array}{c}\text { Total } \\
\text { grasses }\end{array}$ & EROD & OF & $\begin{array}{l}\text { Total } \\
\text { forbs }\end{array}$ & $\begin{array}{c}\text { Total } \\
\text { density }\end{array}$ \\
\hline & \multicolumn{8}{|c|}{ Number of plants per $100 \mathrm{~cm}$} \\
\hline \multicolumn{9}{|l|}{$1969-70$} \\
\hline Time of treatment $t$ & 71 & 1 & 26 & 98 & 1 & 36 & 37 & 135 \\
\hline Fall......................... & 146 & 12 & 56 & 214 & 15 & 123 & 138 & 352 \\
\hline Winter...................... & 110 & 26 & 76 & 212 & 6 & 79 & 85 & 297 \\
\hline Early spring............. & 252 & 8 & 26 & 286 & 10 & 78 & 88 & 374 \\
\hline Late spring................. & 0 & 0 & 0 & 0 & 0 & 0 & 0 & 0 \\
\hline \multicolumn{9}{|l|}{$1970-71$} \\
\hline Time of treatment $\dagger$ & 104 & 74 & 13 & 191 & 4 & 155 & 159 & 350 \\
\hline Fall........................ & 78 & 29 & 23 & 130 & 6 & 119 & 124 & 239 \\
\hline Winter......................... & 63 & 21 & 36 & 120 & 7 & 87 & 94 & 214 \\
\hline Early spring................ & 77 & 10 & 22 & 109 & 6 & 81 & 87 & 196 \\
\hline Late spring............. & 49 & 0 & 15 & 64 & 2 & 50 & 52 & 116 \\
\hline \multicolumn{9}{|l|}{$1971-72$} \\
\hline Time of treatment $\dagger$ & 170 & 330 & 12 & 512 & 92 & 14 & 106 & 618 \\
\hline Fall...................... & 141 & 243 & 31 & 415 & 55 & 94 & 149 & 564 \\
\hline 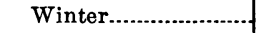 & 108 & 263 & 15 & 346 & 29 & 100 & 129 & 475 \\
\hline Early spring......... & 99 & 146 & 4 & 249 & 20 & 121 & 141 & 390 \\
\hline Late spring................ & 69 & 32 & 2 & 103 & $\mathbf{5}$ & 27 & 32 & 135 \\
\hline \multirow[b]{2}{*}{ Time of sampling } & \multicolumn{8}{|c|}{ South check* } \\
\hline & Brmo & Vume & $O G$ & $\begin{array}{c}\text { Total } \\
\text { grasses }\end{array}$ & EROD & OF & $\begin{array}{l}\text { Total } \\
\text { forbs }\end{array}$ & $\begin{array}{c}\text { Total } \\
\text { density }\end{array}$ \\
\hline & \multicolumn{8}{|c|}{ Number of plants per $100 \mathrm{~cm}^{2}$} \\
\hline \multicolumn{9}{|c|}{ 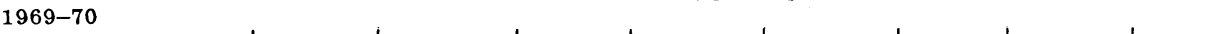 } \\
\hline Time of treatment $\dagger$ & 47 & 39 & 18 & 104 & 12 & 20 & 32 & 136 \\
\hline Fall......................... & 134 & 243 & 34 & 411 & 13 & 70 & 83 & 494 \\
\hline Winter..................... & 72 & 162 & 61 & 295 & $\mathbf{5}$ & 44 & 49 & 344 \\
\hline Early spring............... & 79 & 175 & 9 & 263 & 4 & 32 & 36 & 299 \\
\hline Late spring.................. & 0 & 0 & 0 & 0 & 0 & 0 & 0 & 0 \\
\hline \multicolumn{9}{|l|}{$1970-71$} \\
\hline Time of treatment $\dagger$ & 57 & 90 & 1 & 148 & 31 & 49 & 80 & 228 \\
\hline Fall........................... & 41 & 45 & 10 & 96 & 26 & 40 & 66 & 162 \\
\hline Winter................. & 30 & 30 & 25 & 85 & 20 & 29 & 49 & 134 \\
\hline Early spring............... & 46 & 29 & 13 & 88 & 23 & 23 & 46 & 134 \\
\hline Late spring................ & 36 & 6 & 9 & 51 & 9 & 7 & 16 & 67 \\
\hline \multicolumn{9}{|l|}{$1971-72$} \\
\hline Time of treatment $\dagger$ & 35 & 10 & 1 & 46 & 69 & 23 & 92 & 138 \\
\hline Fall...................... & 101 & 213 & 16 & 330 & 58 & 77 & 135 & 465 \\
\hline Winter.......................... & 73 & 244 & 63 & 380 & 59 & 74 & 133 & 513 \\
\hline Early spring.............. & 61 & 163 & 7 & 240 & 58 & 52 & 105 & 345 \\
\hline Late spring................ & 38 & 44 & 2 & 84 & 16 & 15 & 31 & 115 \\
\hline
\end{tabular}




\begin{tabular}{|c|c|c|c|c|c|c|c|c|}
\hline \multirow{2}{*}{ Time of sampling } & \multicolumn{8}{|c|}{ North paraquat* } \\
\hline & Brmo & Vume & OG & $\begin{array}{c}\text { Total } \\
\text { grasses }\end{array}$ & EROD & OF & $\begin{array}{l}\text { Total } \\
\text { forbs }\end{array}$ & $\begin{array}{c}\text { Total } \\
\text { density }\end{array}$ \\
\hline & \multicolumn{8}{|c|}{ Number of plants per $100 \mathrm{~cm}^{*}$} \\
\hline \multicolumn{9}{|l|}{$1969-70$} \\
\hline Time of treatment $\dagger$ & 71 & 1 & 26 & 98 & 1 & 36 & 37 & 135 \\
\hline 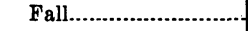 & 16 & 5 & 15 & 36 & 0 & 49 & 49 & 85 \\
\hline 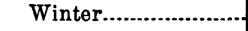 & 15 & 0 & 0 & 15 & 18 & 46 & 64 & 79 \\
\hline Early spring.................. & 27 & 5 & 0 & 32 & 0 & 88 & 88 & 120 \\
\hline Late spring............... & 0 & 0 & 0 & 0 & 0 & 0 & 0 & 0 \\
\hline \multicolumn{9}{|l|}{ 1970-71 } \\
\hline Time of treatment $\dagger$ & 104 & 74 & 18 & 191 & 4 & 155 & 159 & 350 \\
\hline Fall......................... & 1 & 1 & 1 & 3 & 0 & 8 & 8 & 11 \\
\hline 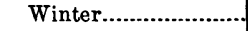 & 1 & 1 & 1 & 3 & 0 & 4 & 4 & 7 \\
\hline Early spring................. & 1 & 1 & 2 & 4 & 0 & 12 & 12 & 16 \\
\hline Late spring................ & 2 & $\mathbf{0}$ & 2 & 4 & 0 & 6 & 6 & 10 \\
\hline \multicolumn{9}{|l|}{$1971-72$} \\
\hline Time of treatment $\dagger$ & 170 & 330 & 12 & 512 & 92 & 14 & 106 & 618 \\
\hline Fall......................... & 20 & 17 & 0 & 37 & 0 & 0 & 0 & 37 \\
\hline 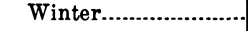 & 1 & 1 & 1 & $\mathbf{3}$ & 1 & 19 & 20 & 23 \\
\hline Early spring............. & 3 & 1 & 0 & 4 & 0 & 18 & 18 & 22 \\
\hline Late spring............... & 6 & 0 & 1 & 7 & 2 & 13 & 15 & 22 \\
\hline \multirow{2}{*}{ Time of sampling } & \multicolumn{8}{|c|}{ South paraquat* } \\
\hline & Brmo & Vume & OG & $\begin{array}{l}\text { Total } \\
\text { grasses }\end{array}$ & EROD & OF & $\begin{array}{l}\text { Total } \\
\text { forbs }\end{array}$ & $\begin{array}{r}\text { Total } \\
\text { density }\end{array}$ \\
\hline
\end{tabular}

\begin{tabular}{|c|c|c|c|c|c|c|c|c|}
\hline \multirow[b]{2}{*}{$1969-70$} & \multicolumn{8}{|c|}{ Number of plants per $100 \mathrm{~cm}^{2}$} \\
\hline & & & & & & & & \\
\hline Time of treatment $\dagger$ & 47 & 39 & 18 & 104 & 12 & 20 & 32 & 136 \\
\hline Fall.................................. & 32 & 124 & 4 & 160 & 0 & 51 & 51 & 211 \\
\hline Winter......................... & 26 & 76 & 4 & 106 & 0 & 85 & 85 & 191 \\
\hline Early spring............... & 16 & 80 & 60 & 156 & 0 & 110 & 110 & 266 \\
\hline Late spring................ & 0 & 0 & 0 & 0 & 0 & 0 & 0 & 0 \\
\hline $1970-71$ & & & & & & & & \\
\hline Time of treatment + & $\mathbf{5 7}$ & 90 & 1 & 148 & 31 & 49 & 80 & 228 \\
\hline Fall.................................. & 1 & 1 & 1 & $\mathbf{3}$ & 0 & 4 & 4 & 7 \\
\hline Winter............................. & 0 & 1 & 1 & 2 & $\mathbf{0}$ & $\mathbf{5}$ & 5 & $\mathbf{7}$ \\
\hline Early spring............. & 0 & 0 & $\mathbf{2}$ & 2 & 0 & 9 & 9 & 11 \\
\hline Late spring............ & 2 & 0 & 3 & 5 & 0 & 6 & 6 & 11 \\
\hline $1971-72$ & & & & & & & & \\
\hline Time of treatment $\dagger$ & 35 & 10 & 1 & 46 & 69 & 23 & 92 & 138 \\
\hline Fall.............................. & 18 & 3 & 0 & 21 & 1 & $\mathbf{3}$ & 4 & 25 \\
\hline 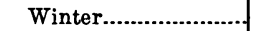 & 17 & 20 & 2 & 38 & 0 & 27 & 27 & 65 \\
\hline Early spring................ & 13 & 10 & 2 & 25 & 1 & 18 & 19 & 44 \\
\hline 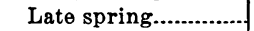 & 8 & 7 & 12 & 27 & 0 & 7 & 7 & 34 \\
\hline
\end{tabular}

*Plant communities were sampled weekly and composited into four intervals during the growing period. Fall includes sampling in October, November, and December; winter in January and February; early spring in March and April; and late spring in May. Symbols used are: Brmo for soft chess (Bromus mollis); Vume for foxtail fescue (Vulpia megalura); EROD for filaree (Erodium botrys, $E$. obtusiplicatum, and $E$. cicutarium); OG for other grass species (refer to text for species); OF for other broadleaved species (refer to text for species)

$\dagger$ This sample was taken just before spraying and seeding in each year.

mental Range in a 3-year study (Biswell and Graham, 1956). At Hopland, densities varied from 0 to 1,410 plants per $100 \mathrm{~cm}^{2}$ in single samples with average densities (40 samples) varying from 51 to 542 per $100 \mathrm{~cm}^{2}$ on three sites during five successive growing seasons (Heady, 1958).

Species response. Densities of individual species varied with year, with aspect, and with paraquat use (table 2).

Among the dominant species, soft 
chess was more prevalent on north slopes and foxtail fescue and Erodium spp. on south slopes. To a less extent, the other grasses and broadleaved species had higher densities on north slopes than on south.

On the north slope, densities were greatest for soft chess and other grass species in 1969-70, and for foxtail fescue and Erodium spp. in 1971-72. The other broadleaved species remained rather constant in all 3 years. In 1970 71 , densities of all species or groups of species, except other broadleaved plants, remained relatively low.

On the south slope, Erodium spp. had greater density in 1971-72 than in other years. The other grasses had somewhat greater density in 1969-70. No other differences were noted, except that all species tended to have lower densities in 1970-71, as on the north slope.

Paraquat markedly reduced the density of all species and species groups, except that of other broadleaf plants. On paraquat plots, an alternate flora developed which was dominated by silver hairgrass, common chickweed, and erect plantain (Evans et al., 1973). The broadleaved plant component of this flora accounted for less of a decrease for this general group.

Herbage production. Total production of herbage by annual plant species (biomass of the aboveground part) varied. It ranged from about 2,000 to $2,700 \mathrm{~kg} / \mathrm{ha}$ in years when soil moisture became unavailable in the last part of April to the first part of May (1969-70 and 1971-72). Production ranged from about 2,800 to $4,600 \mathrm{~kg} / \mathrm{ha}$ in $1970-71$ when available moisture persisted in the soil until late June or early July (table 3).

Production of annual plants in all 3 years was influenced greatly by temperature during the growing season. Yield remained low, averaging $820 \mathrm{~kg} / \mathrm{ha}$, until the middle of March when accelerated growth accompanied increased temperature.

Besides drastically reducing the density of annual plants, paraquat curtailed production until the last of February or the middle of March in every year. Between this time and the end of the growing season, production on paraquat plots nearly equaled that on un-

TABLE 3

PRODUCTION OF ANNUAL PLANTS (KG PER HECTARE) THROUGH THE GROWING PERIOD ON TREATED AND UNTREATED PLOTS OF NORTH AND SOUTH SLOPES, 1969-1972

\begin{tabular}{|c|c|c|c|c|}
\hline Time of sampling* & $\begin{array}{l}\text { North } \\
\text { check }\end{array}$ & $\begin{array}{c}\text { North } \\
\text { paraquat }\end{array}$ & $\begin{array}{l}\text { South } \\
\text { check }\end{array}$ & $\begin{array}{c}\text { South } \\
\text { paraquat }\end{array}$ \\
\hline & \multicolumn{4}{|c|}{ kg per hectare } \\
\hline \multicolumn{5}{|l|}{$1969-70$} \\
\hline Fall.................. & 690 & 80 & 610 & 80 \\
\hline 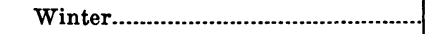 & 990 & 190 & 1,180 & 390 \\
\hline 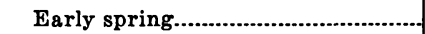 & 2,100 & 1,060 & 2,070 & 1,360 \\
\hline 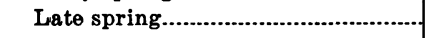 & 0 & 0 & 0 & 0 \\
\hline \multicolumn{5}{|l|}{$1970-71$} \\
\hline 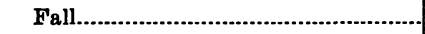 & 250 & 0 & 520 & 0 \\
\hline 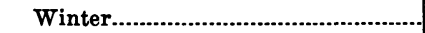 & 540 & 0 & 820 & 0 \\
\hline Early spring & 1,830 & 600 & 2,340 & 550 \\
\hline 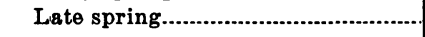 & 2,760 & 1,530 & 4,640 & 2,690 \\
\hline \multicolumn{5}{|l|}{$1971-72$} \\
\hline 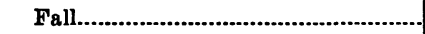 & 350 & 0 & 350 & 0 \\
\hline 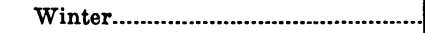 & 570 & 10 & 820 & 20 \\
\hline 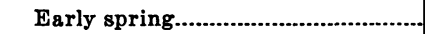 & 2,090 & 1,050 & 2,210 & 1,250 \\
\hline 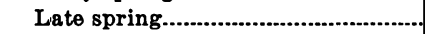 & 2,710 & 1,980 & 2,640 & 2,280 \\
\hline
\end{tabular}

* Yield sampled weekly and composited in four intervals during growing period. 
sprayed plots in 1971-72. In 1969-70, a year when soil moisture was depleted early, production on paraquat plots was about half that on unsprayed plots (as it was in 1970-71) even though soil moisture remained available until later in the year. In 1970-71 paraquat was most effective in reducing density of annuals, and the lowered density simply did not permit production equal to that in unsprayed areas.

Establishment of replacement species. In 1969-70, establishment of hardinggrass was nil on both slopes and on check and paraquat plots alike. In November 1969, about 20 subclover seedlings per meter had emerged. There were no differences in emergence because of aspect or paraquat treatment. In April 1970, the stocking rate (frequency of occurrence in 7 -cm samples) of subclover was about 40 per cent on the control and 50 per cent on paraquat plots. Stand establishment was the same on north and south slopes.

In 1970-71, establishment of rose clover ( 82 per cent) was twice that of subclover (42 per cent) on both slopes. Aspect affected the frequency of neither species. Frequency of clover plants was the same on paraquat and check plots, though individual plant size on the south-slope paraquat plots was twice that on control plots in the early growing season (February 27, 1971), as determined by oven-dry weight. Rose clover yielded $18 \mathrm{mg}$ per plant on check plots vs $35 \mathrm{mg}$ on paraquat-sprayed plots, and subclover yielded $20 \mathrm{mg}$ vs $41 \mathrm{mg}$. Rose and subclover, respectively, yielded $13 \mathrm{mg}$ and $20 \mathrm{mg}$ per plant in north-slope control plots, and both yielded $21 \mathrm{mg}$ in paraquat plots. Perlagrass frequency in paraquat plots at the end of the growing season was 58 per cent on the north slope and 63 per cent on the south slope. No perlagrass became established on check plots. Frequency of perlagrass in January averaged 82 per cent on paraquat plots and
13 per cent on check plots. Intense competition for light, resulting from the rapid and robust growth of annuals, completely negated establishment of perennial grass on check plots and significantly reduced it even on paraquat plots.

Perlagrass frequency in paraquat plots on January 11, 1972, was 47 per cent on north slopes and 66 per cent on south slopes. This grass did not appear to be established in control plots on either slope at that date. By the end of the growing season, respective frequencies in paraquat plots were 81 per cent and 77 per cent for north and south slopes. Sampling in the next year (March 8, 1973) indicated that stand establishment in paraquat plots was 43 per cent on the north slope and 17 per cent on the south slope. No establishment was found in control plots. Frequency of subclover was low, not exceeding 12 per cent on any slope or treatment. Rose clover had frequencies of 30 per cent on south-slope plots, both paraquat and check, but only 3 per cent establishment on north-slope plots.

Establishment of hardinggrass and perlagrass was related directly to control of annual plants and the accompanying reduction in competition. These two grasses were not compared directly in this study, but the more vigorous seedling growth of perlagrass makes it better suited than hardinggrass to compete with the rapidly growing annuals. In 1969-70, the one year when hardinggrass was seeded, weed control from paraquat was poor, no seedling survived, and no grass was established. In the next 2 years, the combination of better weed control and the more vigorous perlagrass resulted in stand establishment of perennial grasses.

Establishment of annual clovers did not relate directly to reduction of competition from the resident annuals. Establishment and growth were far greater in rose clover than in subclover. 
In 1 year, rose clover frequency was 10 times as great on the south slope as on the north. The cause was probably the more favorable light and temperature regimes of the south aspect.

\section{Interrelations among environmental factors and plant responses}

Available soil moisture permitted seed germination, emergence, and plant growth in this annual rangeland community. Temperature controlled the general rate of plant growth and created detectable differences in terms of plant responses, when it dropped low enough to prevent, or markedly reduce, seed or caryopsis germination or to retard seedling growth. Temperature also affected plant growth when it rose high enough to bring about quicker drying of plants, either directly or indirectly, by causing more rapid depletion of soil moisture.

An inverse relation between favorable temperature and available moisture (typical of the Mediterranean-like climate) was shown in the seasonal trends of the 3 years of the study (fig. 12). This relation is expressed here in more meaningful measurements for growing plants than is usual, however. Instead of temperatures recorded away from the plant environment, these were measured at the growing levels in soil and air very close to the plants. Moisture is usually recorded in terms of precipitation, taken either near to or relatively far from the site. The available moisture given here is in terms of water potential in the root zone of the plants.

The time of coincidence of favorable temperature and available moisture for active plant growth varied quite markedly among years, as did the length of uninterrupted available soil moisture. These variations were reflected in total plant growth, density, and botanical composition in specific years of the study.
When seasonal trends in light intensity are superimposed on trends of temperature and moisture, especially those altered by plant growth, limiting factors affecting plant growth throughout the period form a comprehensive mosaic.

Through the characterization of the microenvironment and its alteration by weed control and the responses of plants to these conditions, it is possible to characterize more clearly the dynamics of the community. It is also possible to define differences of aspect in terms of both microenvironment and plant responses. This approach develops concepts and relations not reported before. Among these, light is (in terms of plant competition) the overriding factor that prevented establishment of perennial grasses in this community. Soil-moisture depletion by adjacent plants through the growing season was of little or no effect except in isolated instances in midseason when soil moisture was rapidly depleted. Further, the shading effect of the canopy of annual plants is vertically restricted to 1 or 2 $\mathrm{cm}$ above the soil surface during crucial periods of emergence and growth of the seeded species. Light intensity at 3 to 6 $\mathrm{cm}$ approximated that of full illumination during this period. Even during midwinter, when illumination is lowest, there were days of considerable light intensity (with much variability between days), when there was no shading effect of a closed canopy of annual plants With a closed canopy, in contrast, light intensity through this entire period remained very low. The seeded annual clovers were not as vulnerable to these low light levels as were the Phalaris species. Rose clover was, apparently, more tolerant of shade competition than was subclover.

Microenvironmental data, besides furthering understanding of complex phenomena of the ecosystem, establish benchmark or standard regimes of tem- 


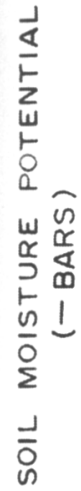

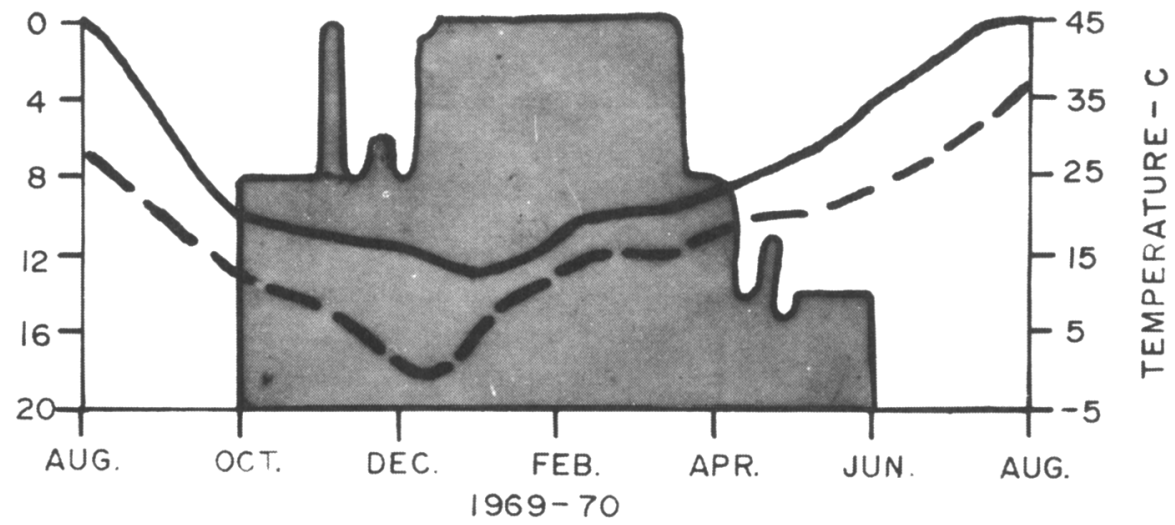

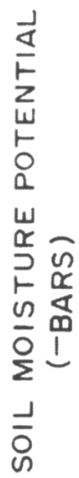

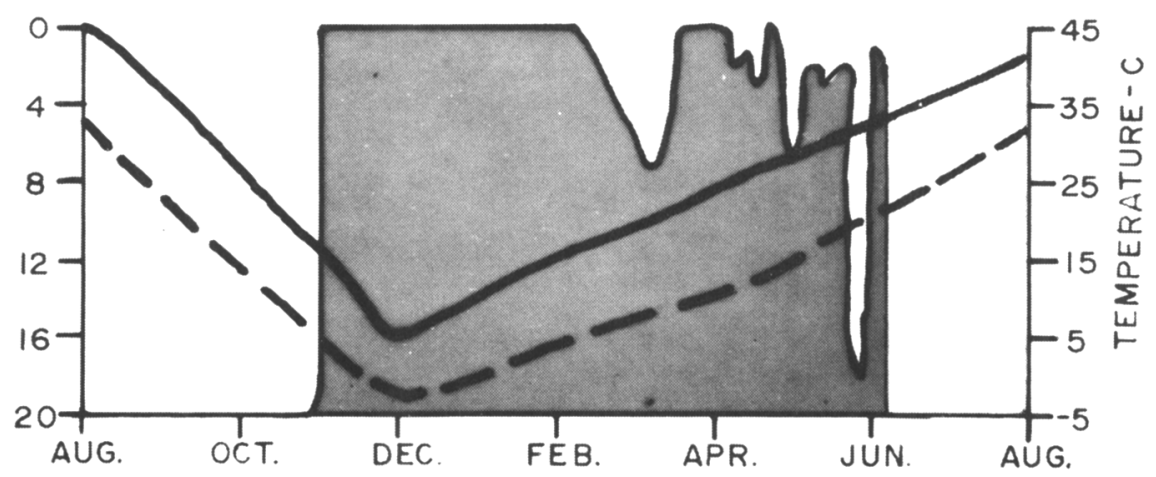

$1970-71$

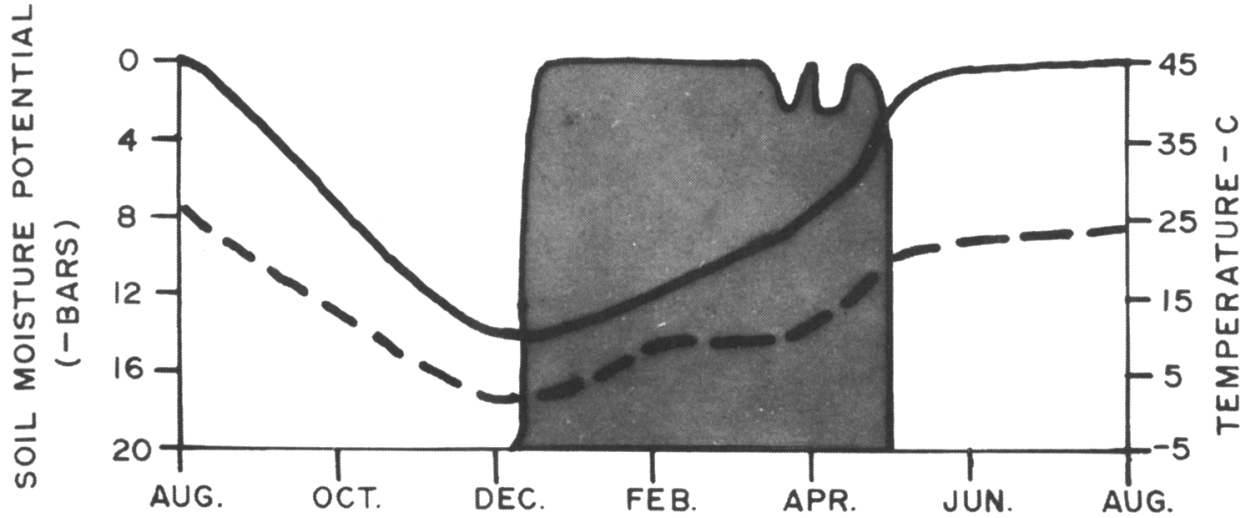

$1971-72$

Fig. 12. Duration of soil moisture (shaded area) and general trends of day (solid line) and night (dashed line) air temperatures measured close to plants in an annual rangeland community in (A) 1969-70, (B) 1970-71, and (C) 1971-72. 
perature, light, and soil moisture for laboratory experiments of seed germination, seedling growth, and other plant responses. These studies, in turn, answer questions about the dynamics of plant communities.

\section{LITERATURE CITED}

Biswell, H. H.

1956. Ecology of California grasslands. J. Range Manage. 9:19-24.

Biswell, H. H., and C. A. Graham

1956. Plant counts and seed production on California annual-type ranges. J. Range Manage. 9:116-18.

Evans, R. A., H. R. Holbo, R. E. Eckert, Jr., and J. A. Young

1970. Functional environment of downy brome communities in relation to weed control and revegetation. Weed Sci. 18:154-62.

Evans, R. A., and J. A. Young

1970. Plant litter and establishment of alien annual species in rangeland communities. Weed Sci. 18:697-703.

1972. Competition within the grass community. In: Grass Biology and Utilization. V. P. Youngner and C. M. McKell (eds.). New York, N.Y.: Academic Press. 426 pp.

Evans, R. A., J. A. Young, and B. L. Kay

1973. Germination of winter annual species from a rangeland community treated with paraquat. Weed Sci. 22:185-87.

Heady, H. F.

1958. Vegetational changes in the California annual type. Ecology 39:402-16.

Hsieh, J. H. C., and F. P. Hungate

1969. Temperature compensated peltier psychrometers for measuring plant and soil water potentials. Soil Sci. 110:253-57.

Hughes, A. P.

1966. The importance of light compared with other factors affecting plant growth. In: Light as an Ecological Factor. R. Bainbridge, G. C. Evans, and O. Rackham (eds.). New York, N.Y.: John Wiley and Sons. $452 \mathrm{pp}$.

Kay, B. L., and R. E. Owen

1970. Paraquat for range seeding in cismontane California. Weed Sci. 18:238-43.

Love, R. M.

1952. Range improvement experiments at the Arthur Brown Ranch, California. J. Range Manage. 53:120-23.

Robbins, W. W.

1940. Alien plants growing without cultivation in California. Calif. Agr. Exp. Sta. Bul. 637:1-128.

Young, J. A., R. A. Evans, and B. L. Kay

1970. Germination characteristics of range legumes. J. Range Manage. 23:98-103.

1971. Germination of caryopses of annual grasses in simulated litter. Agron. J. 63:551-55.

1973. Temperature requirements for seed germination in an annual-type rangeland com. munity. Agron. J. 65:656-59.

Young, J. A., and R. A. Evans

1972. Conversion of medusahead to downy brome communities with diuron. J. Range Manage. 25:40-43. 
plants directly, or indirectly by more rapid depletion of soil moisture. The overriding factor of competition which prevented establishment of hardinggrass and perlagrass was interception of light by the canopy of annual plants during the growing season. The shading effect was most severe at ground level. During crucial periods of emergence and growth of the seeded species, this shading was virtually restricted to 1 or $2 \mathrm{~cm}$ above the surface. Soil-moisture depletion mattered primarily at the end of the growing season, but in some restricted periods during the season it became an important factor. 
The journal HILGARDIA is published at irregular intervals, in volumes of about 650 to 700 pages. The number of issues per volume varies.

Single copies of any issue may be obtained free, as long as the supply lasts; please request by volume and issue number from:

\title{
PUBLICATIONS \\ DIVISION OF AGRICULTURAL SCIENCES \\ UNIVERSITY OF CALIFORNIA
}

\author{
14.22 South 10th Street \\ Richmond, California 94804
}

The limit to nonresidents of California is 10 separate titles. The limit to California residents is 20 separate titles.

The journal will be sent regularly to libraries, schools, or institutions in one of the following ways:

1. In exchange for similar published material on research.

2. As a gift to qualified repository libraries only.

3. On a subscription basis- $\$ 7.50$ a year paid in advance. All subscriptions will be started with the first number issued during a calendar year. Subscribers starting during any given year will be sent back numbers to the first of that year and will be billed for the ensuing year the following January. Make checks or money orders payable to The Regents of The University of California; send payment with order to Agricultural Publications at above address. 